\title{
Middle Holocene Climate Oscillations Recorded in the Western Dvina Lakeland
}

\author{
Agnieszka Mroczkowska 1,2,*(D), Dominik Pawłowski ${ }^{3}\left(\mathbb{D}\right.$, Emilie Gauthier $^{4}\left(\mathbb{D}\right.$, Andrey Mazurkevich ${ }^{5}$, \\ Tomi P. Luoto ${ }^{6}(\mathbb{D})$, Odile Peyron ${ }^{7}\left(\mathbb{D}\right.$, Bartosz Kotrys ${ }^{8}\left(\mathbb{D}\right.$, Stephen J. Brooks ${ }^{9}$, Larisa B. Nazarova ${ }^{10,11}{ }^{(D)}$, \\ Liudmila Syrykh $^{12}$ D, Ekaterina V. Dolbunova ${ }^{5}$, Eva Thiebaut ${ }^{4}$, Mateusz Płóciennik ${ }^{13}$, \\ Olga Antczak-Orlewska ${ }^{14}$ (D) and Piotr Kittel ${ }^{1}$ (D)
}

1 Department of Geology and Geomorphology, Faculty of Geographical Sciences, University of Lodz, Narutowicza 88, 90-139 Lodz, Poland; piotr.kittel@geo.uni.lodz.pl

2 Stanisław Leszczycki Institute of Geography and Spatial Organisation, Polish Academy of Sciences, Twarda 51/55, 00-818 Warsaw, Poland

3 Faculty of Geographical and Geological Sciences, Institute of Geology, Adam Mickiewicz University, B. Krygowskiego 12, 61-680 Poznan, Poland; dominikp@amu.edu.pl

4 Laboratoire Chrono-Environnement, UMR CNRS/6249, Université de Bourgogne Franche-Comté, 25000 Besançon, France; emilie.gauthier@univ-fcomte.fr (E.G.); tanypodinae1@wp.pl (E.T.)

5 The State Hermitage Museum, Dvortsovaya Naberezhnaya 34, 190000 St. Petersburg, Russia; a-mazurkevich@mail.ru (A.M.); katjer@mail.ru (E.V.D.)

6 Ecosystems and Environment Research Programme, Faculty of Biological and Environmental Sciences, University of Helsinki, 73 Niemenkatu, FI-15140 Lahti, Finland; tomi.luoto@helsinki.fi

check for updates

Citation: Mroczkowska, A.; Pawłowski, D.; Gauthier, E.; Mazurkevich, A.; Luoto, T.P.; Peyron, O.; Kotrys, B.; Brooks, S.J.; Nazarova, L.B.; Syrykh, L.; et al. Middle Holocene Climate Oscillations Recorded in the Western Dvina Lakeland. Water 2021, 13, 1611. https://doi.org/10.3390/w13111611

Academic Editors: Michał Słowiński and Natalia Rudaya

Received: 19 April 2021

Accepted: 28 May 2021

Published: 7 June 2021

Publisher's Note: MDPI stays neutral with regard to jurisdictional claims in published maps and institutional affiliations.

Copyright: (c) 2021 by the authors. Licensee MDPI, Basel, Switzerland. This article is an open access article distributed under the terms and conditions of the Creative Commons Attribution (CC BY) license (https:/ / creativecommons.org/licenses/by/ $4.0 /)$.
7 Institut des Sciences de l'Evolution de Montpellier ISEM, Université de Montpellier, CNRS, IRD, EPHE, 34095 Montpellier, France; odile.peyron@umontpellier.fr

8 Polish Geological Institute-National Research Institute, Pomeranian Branch in Szczecin, 71-130 Szczecin, Poland; bkotr@pgi.gov.pl

9 Department of Life Sciences, Natural History Museum, Cromwell Road, London SW7 5BD, UK; s.brooks@nhm.ac.uk

10 Institute of Geoscience, Potsdam University, 14476 Potsdam, Germany; larisa.nazarova@awi.de

11 Institute of Management and Territorial Development, Kremlevskaya, Kazan Federal University, Kremlyovskaya Str., 18, 420008 Kazan, Russia

12 Department of Physical Geography \& Environment, Herzen State Pedagogical University of Russia, 191186 St. Petersburg, Russia; lyudmilalsd@gmail.com

13 Department of Invertebrate Zoology \& Hydrobiology, Faculty of Biology and Environmental Protection, University of Lodz, Banacha 12/16, 90-237 Lodz, Poland; mateusz.plociennik@biol.uni.lodz.pl

14 Laboratory of Palaeoecology and Archaeobotany, Department of Plant Ecology, Faculty of Biology, University of Gdansk, Wita Stwosza 59, 80-308 Gdańsk, Poland; olga.antczak-orlewska@ug.edu.pl

* Correspondence: agnieszka.mroczkowska@twarda.pan.pl

Abstract: Although extensive archeological research works have been conducted in the Serteya region in recent years, the Holocene climate history in the Western Dvina Lakeland in Western Russia is still poorly understood. The Neolithic human occupation of the Serteyka lake-river system responded to climate oscillations, resulting in the development of a pile-dwelling settlement between 5.9 and $4.2 \mathrm{ka}$ cal BP. In this paper, we present the quantitative paleoclimatic reconstructions of the Northgrippian stage (8.2-4.2 ka cal BP) from the Great Serteya Palaeolake Basin. The reconstructions were created based on a multiproxy (Chironomidae, pollen and Cladocera) approach. The mean July air temperature remained at $17-20^{\circ} \mathrm{C}$, which is similar to the present temperature in the Smolensk Upland. The summer temperature revealed only weak oscillations during 5.9 and $4.2 \mathrm{ka}$ cal BP. A more remarkable feature during those events was an increase in continentality, manifested by a lower winter temperature and lower annual precipitation. During the third, intermediate oscillation in 5.0-4.7 ka cal BP, a rise in summer temperature and stronger shifts in continental air masses were recorded. It is still unclear if the above-described climate fluctuations are linked to the North Atlantic Oscillation and can be interpreted as an indication of Bond events because only a few high-resolution paleoclimatic reconstructions from the region have been presented and these reconstructions do not demonstrate explicit oscillations in the period of 5.9 and $4.2 \mathrm{ka} \mathrm{cal} \mathrm{BP.}$ 
Keywords: paleolimnology; lake sediment; multiproxy reconstruction; 5.9 and 4.2 climate event; climate change; Western Russia

\section{Introduction}

Neolithization processes in Central and Northern Europe were mainly caused by climate fluctuations, especially during the period between 8.2 and $6 \mathrm{ka}$ cal BP [1]. The cold event in $8.2 \mathrm{ka}$ cal BP caused the migration of Neolithic communities northward from the steppe area of the Black Sea Lowland region toward the coniferous and mixed forest belt of the East European Plain [2]. The rise of temperature in Northern Europe in ca. $6 \mathrm{ka}$ cal BP favored agriculture dispersion and an increase of population in the circum-Baltic Region [3]. In the Central-Western European territories, the expansion of Linear Pottery Culture communities appears to coincide with wet and relatively warm winters and cool summers [1], which was also supported by quantitative paleoclimatic studies. Several paleotemperature records from the E Scandinavia and NW Russia were cited by Kaufman et al. [4], e.g., two quantitative reconstructions based on pollen data [5,6] and one based on Chironomidae [7,8].

Paleoclimatic research is less developed in Eastern Europe compared to the western part of the continent [2,9-11]. Thus, the paleoclimatic background for archeological discoveries on Mesolithic and Neolithic cultures in Eastern Europe is still insufficient. Good qualitative data, unfortunately, the temperature reconstructions are not available for the following publication: Tallinn region (Estonia) [12], Myshetskoe-Dolgoe Lake in Moscow [13], Lake Kenozero [14], Ukraine and Belarus [15,16]. However, plant communities in the area reveal a lagged response to short-lived temperature oscillations that might have been crucial for human settlement, which made it possible to adopt different nutritional strategies at different times.

Aquatic invertebrates are more reactive and sensitive to short-term changes in temperature than plants [17]. Chironomids (Chironomidae), a midge group within the Culicomorpha (Diptera) infraorder, have short life cycles and respond sensitively to climate changes with a decadal resolution [18]. Their development is strongly influenced by environmental conditions [19,20]. The characteristics of Chironomids, namely species diversity, short life cycles, and sensitivity to environmental conditions, make them one of the most reliable proxies for summer air reconstructions [18,21].

Although the summer temperature is crucial for vegetation in temperate to boreal biomes, and influences the economy of the Neolithic communities, precipitation also determines primitive agriculture as well as a hunter-gatherer subsistence strategy. The effective long-term precipitation may be estimated from changes in lake level [22]. Alongside chironomids, small crustaceans of the order Cladocera are very sensitive to lake level fluctuations, as many of the Cladocera taxa are planktonic [23,24]. Therefore, cladocerans can be successfully used for water level reconstructions $[25,26]$. These microcrustaceans also indicate changes in the trophic status of lakes, including human-environment relationships [27], lake levels [28] including overbank episodes in floodplain areas [29,30], and climate change [31,32]. The Holocene lake level changes are very well documented for Eastern Europe. In the case of the East Peribaltic Region, lake levels and climate wetness were recorded from Northern Poland [33-35] and Baltic States [36-40]. Currently, the entire Holocene sequence from the East European Plain can be found in as many as 50 lake records [41,42]. From Eastern Europe quantitative reconstruction have been made from pollen-inferred paleotemperature and precipitation at Mshinskoye raised bog and Lembolovskoye Lake [43], Bobrovichskoe and Oltushskoe (Polesye) [44], Upper Don [45] and Myshetskoe-Dolgoe Lake [13]. Also pollen-inferred Holocene paleotemperature data from Nikokolsko-Lutinskoye bog, Shirinsky Mokh bog, Lammin-Suo bog, Vishnevskoye Lake and Sakkala bog [46] are available. Chironomid-based mean July air temperature reconstructions are available from Nikolay Lake [47], Lake Medvedevskoe [48] and Lake 
Glubokoye $[49,50]$. One of the important regions in terms of East European paleoclimatology is the Western Dvina Lakeland (Western Russia), where the terrain relief was formed after the recession of the Valdai Ice Sheet [51]. This region was considered crucial for studying the development of human settlement [52-55]. The Neolithic occupation in this area began at ca. $8.3 \mathrm{ka}$ cal BP, and the development of Neolithic communities lasted up to around $3.8 \mathrm{ka}$ cal BP $[53,54,56,57]$. The pile-dwelling settlement existed in the region during the Middle and Late Neolithic period (between 5.9 and $4.2 \mathrm{ka}$ cal BP) [53,58]. The existence of Neolithic communities in this part of Europe was based on a hunter-gatherer subsistence strategy. The elements of agriculture were adopted gradually only in the Late Neolithic (from ca. $3.8 \mathrm{ka}$ cal BP) [59-62]. However, the local production of biocenoses was influenced by climate variability, particularly mean July air temperature ( $\mathrm{T} J u l)$, precipitation, and duration of the growing season. Hunter-gatherer communities were also dependent on climate conditions [55]. Thus, the sudden climate fluctuations linked to the Bond events, during 5.9 and $4.2 \mathrm{ka}$ cal BP, might have triggered cultural changes in the Serteya region, forcing a lifestyle change due to the lower productivity of lake and terrestrial ecosystems, lake level fluctuations, and changes in snow cover.

Bond events are climate fluctuations in the Holocene which are based on petrological traces of drifting ice in the North Atlantic over a 1000-year cycle [63,64]. The possible causes for these events include: (1) Orbital insolation—changes in the Earth's orbit are, however, a process too long to cause a 1000-year fluctuation [65]. Solar irradiance-it is contested at event 4.2, where the peak values of ${ }^{14} \mathrm{C}$ and ${ }^{10} \mathrm{Be}$ were very low [66], and is speculated as a possible cause of a decrease in the amount of ultraviolet radiation that may have cooled the ozone layer. These changes could ignite the negative North Atlantic oscillation (NAO) phase, which transported cold and dry air masses over Northern Europe $[67,68]$. The NAO phenomena in the Holocene correspond chronologically to a decrease in solar activity (increase in ${ }^{14} \mathrm{C}$ and ${ }^{10} \mathrm{Be}$ ) [63]. NAO is a circulation system that determines mostly autumn and winter weather conditions in Europe. It is the transition between the positive and negative phases which are distinguished by the amount of atmospheric pressure. Based on the observations of the fluctuations connected with global air circulation and oceanic water, it is known that the NAO is characterized by two phases: positive and negative. The positive phase involves the transfer of warm and humid air masses from the Atlantic Ocean in the direction of Northeastern Europe, while in the negative phase warm and humid air masses move toward the Mediterranean area, causing drought due to decreased snowfall in the northeastern part of Europe [69-71]. (2) Volcanic activity-it is possible only with huge eruptions, but according to Cronin et al. [72] even the largest ones may cause a reduction of the global temperature by only $0.2-0.3^{\circ} \mathrm{C}$ for one to several years. There were 12 volcanic eruptions during the Little Ice Age [73]. (3) Ice-sheet dynamics-the melting of icebergs lowers salinity, while decreasing THC (thermohaline circulation) causes negative feedback leading to ice growth in Laurentide [72,74,75].

This paper presents quantitative reconstructions of the main climate factors (mean summer and winter air temperature, and precipitation) influencing the neolithization processes in Eastern Europe, especially the activities related to human occupation in the Western Dvina Lakeland from the $5.9 \mathrm{ka}$ cal BP event (at 6.0-5.75 ka cal BP) to the 4.2-ka cal BP event (at 4.43-3.97 ka cal BP). The T Jul, lake water level related to effective precipitation, mean temperature of the coldest month (TCM), and annual precipitation (AnP) were inferred from the analyses of Chironomidae, Cladocera, and pollen assemblages $[18,25,76]$ and Nazarova et al. unpublished data). We aimed to identify the scale of temperature fluctuations in the region and climate wetness phases. According to the null hypothesis, during the Northgrippian stage (Middle Holocene), the mean July temperature and climate humidity did not vary significantly in the Eastern European Plain and were not decisive for the late emergence of agriculture in the Serteya area. Alternatively, we hypothesized that significant climate changes, coincident with global events, took place during the mid-Holocene. These changes might influence the long-term development of the Serteya II settlement, e.g.: a switch to the Neolithic culture at $8.2 \mathrm{ka}$ cal BP, the development of 
the pile-dwelling settlement at $4.2 \mathrm{ka}$ cal BP, the prolonged existence of a hunter-gatherer subsistence strategy, and the late emergence of agriculture after $4.2 \mathrm{ka}$ cal BP $[57,77]$.

\section{Study Area}

The Serteya region, including the Serteyka River valley, is situated in Western Russia (the Smolensk Oblast of the Russian Federation), in the vicinity of the European watershed of the Western Dvina (Daugava) River and the Dnieper River Basin (Figure 1). The Serteyka River is a left-bank tributary of the Western Dvina River. According to the physicogeographical division, the Serteya region belongs to the Western Dvina Lakeland [78] or the Vitebsk Lakeland [79]. It lies in the temperate continental climate zone characterized by high-dynamic changes in modern meteorological conditions which strongly influence the natural environment of the area [80]. Winters are moderately cold, with a stable snow cover from November to April, and summers are moderately cool and humid. Much of the AnP (ca. 60\%) falls between the months of May and October. The climate data of Velizh, situated $20 \mathrm{~km}$ west of the site, has an average annual temperature of $3.6^{\circ} \mathrm{C}$ to $8.4^{\circ} \mathrm{C}$ and average annual atmospheric precipitation varying from 488 to $1296 \mathrm{~mm}$ per year for the years 1955-2017. The mean temperature of the warmest month (TWM) (July) varies between $14.8^{\circ} \mathrm{C}$ and $23.0^{\circ} \mathrm{C}$, while that of the coldest month (January) ranges from $-17.7^{\circ} \mathrm{C}$ to $-0.8^{\circ} \mathrm{C}[81]$.

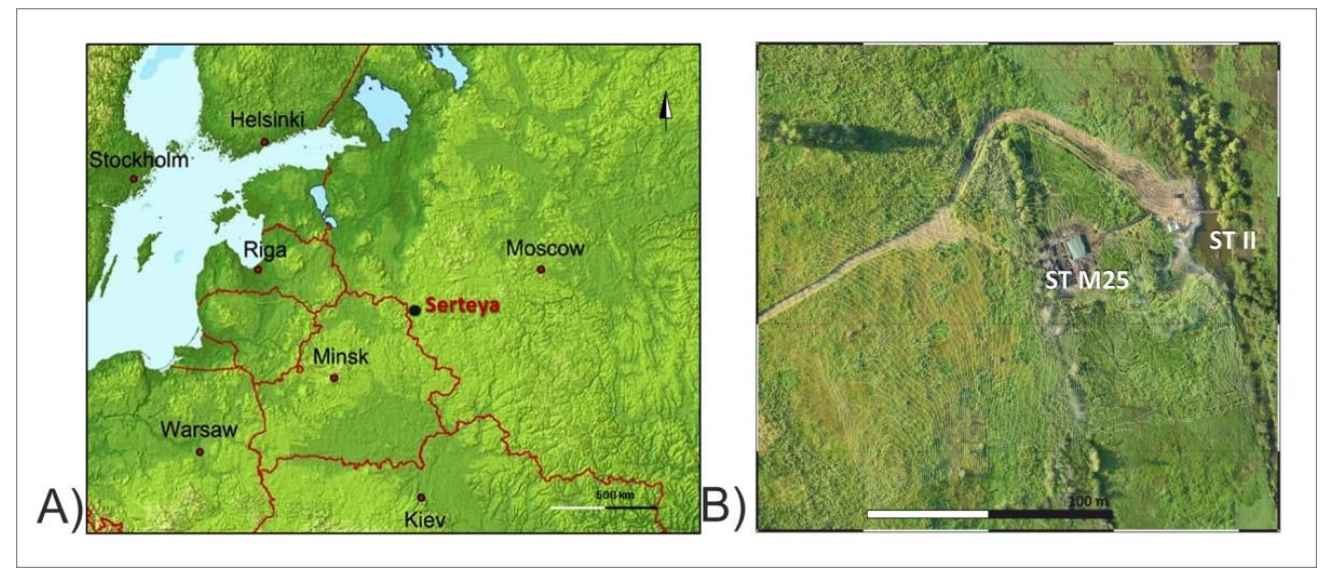

Figure 1. (A) Location of the study area; (B) location of the studied core.

At the end of the Valdai Glaciation, geomorphological processes led to the formation of the land relief framework in the area $[82,83]$. Within the tunnel valley, which is occupied in modern times by the lower Serteyka River valley, a few lake basins existed in the Late Vistulian and during the Holocene. Previous reports indicate that, in the Late Holocene, the lake landscape was gradually replaced by a fluvial system due to the headward erosion and subsequent draining of the lake basins during the development of the Serteyka River valley $[84,85]$. This scheme is similar to that described by Błaszkiewicz [86,87] for the Kociewskie Lakeland, Poland. At present, the Great Serteya Palaeolake Basin is the largest extension of the valley, with a length of ca. $1.2 \mathrm{~km}$ and a width of over $0.5 \mathrm{~km}$ [85].

During the last 30 years of intense archaeological survey, about 60 archaeological sites, originating from different periods since the Late Paleolithic to the Middle Ages, have been discovered in the surrounding area. The results of the long-term archeological research formed the basis for the reconstruction of the human settlement development and economic foundations of communities in the subsequent periods. The human settlement in this area was strongly affected by paleoenvironmental conditions. Previous palynological, diatom, and geochemical research of biogenic sediment cores M25 from the Serteya region provided an insight into the general paleoclimatic situation of the study area. Kittel et al. [57] explained the paleoecological changes of the Great Serteya Palaeolake Basin in the last $6.3 \mathrm{ky} \mathrm{BP}$. Based on previous research of the Neolithic environmental con- 
ditions between ca. 4300 and $1600 \mathrm{cal} \mathrm{BC}$, the period $4150-3250 \mathrm{cal} \mathrm{BC}$ is distinguished as a time of increased settlement activity of Neolithic hunter-gatherers on the paleolake shore. On the basis of ecological proxies, fluctuations in the lake water level and the increase in the lake trophic state caused by human influence were also reconstructed. The results show that the Neolithic community and its functioning were strongly influenced by changing environmental conditions, including climate change. Łuców et al. [88] described the last 300-year ecological history of the Serteya region, based on analysis of the organic sediments of an ombrotrophic fen, which revealed the influence of local anthropogenic disturbances on the functioning of the fen. This work reconstructed climate and lake level change based on three proxies (testate amoeba and pollen, plant macrofossils). In the present study, a complete chronology of the sediment was obtained from AMS radiocarbon dating based on the macrofossils of terrestrial plants [cf. 57]. The chronology used follows Kittel et al. [57]. The results presented below are a further analysis of the data obtained from the deposits of the STII M25 core.

\section{Archeological Investigation}

Two main areas of the Serteya II have been explored so far [52,57]. The eastern part of the site contains the remains of the pile-dwelling structures, which are dated to 5-4 ka cal BP. The western part of the site was first inhabited in the Late Mesolithic period. During the Early Neolithic, periodic settlements were established at 9-6 ka cal BP. At 6-5 ka cal BP, people of Eneolithic steppe cultures were active in the area. Numerous wooden and bone objects, remnants of residential structures, and fishing devices were found at these complexes. In addition, finds from ca. 5-4 ka cal BP belonging to the Usviaty Culture and Zhizhitsa Culture were recorded, similar to materials from pile dwellings found in the eastern part of the site. At ca. $4.5 \mathrm{ka}$ cal BP, the bodies of two young women were deposited in the paleolake shore zone of site's western part $[52,57,89,90]$.

\section{Materials and Methods}

\subsection{Field Studies and Coring}

The geological and geomorphological survey made in 2013-2019 enabled a detailed reconstruction of the geology of the Serteya II site and its vicinity [52,85]. In 2016, a 1.4-m core (STII M25) was taken from the wall of the archeological outcrop in close proximity to the human bones discovered in 2015 [57] covering deposits from 23 to $160 \mathrm{~cm}$ below ground level (b.g.l.). The core was placed in three metal boxes measuring $50 \mathrm{~cm} \times 10 \mathrm{~cm} \times$ $10 \mathrm{~cm}$ in size. It consists of the following deposits [57]:

0-23 cm b.g.l.-20th century AD embankment

23-65 cm b.g.l.-peaty organic mud with sandy admixtures

$65-75 / 80 \mathrm{~cm}$ b.g.l.—carbonate sandy organic mud

75/80-148.5 cm b.g.l.—coarse detritus gyttja

$148.5-160 \mathrm{~cm}$ b.g.l.- - sand and gravel with organic mud and plant detritus

The age of the deposits was determined by Kittel et al. [57] from selected macrofossils of terrestrial plants through 14C AMS (accelerator mass spectrometry) analysis. The calibration and chronology were estimated using OxCal v. 4.4.3 with IntCal 20 calibration curve and P_Sequence model $[91,92]$. For the 1.4-m-long core, a total of six AMS dates, from depths $34,85,116,138,148$, and $158 \mathrm{~cm} \mathrm{b.g.l.,} \mathrm{were} \mathrm{used} \mathrm{for} \mathrm{the} \mathrm{construction} \mathrm{of} \mathrm{the}$ depth-age model (not shown) [57].

\subsection{Paleoecological Analyses}

\subsubsection{Chironomidae - Laboratory Techniques, Identification, and Statistics}

The subfossil Chironomidae assemblage analysis was carried out on the STII M25 core with a resolution of $2 \mathrm{~cm}$. For this purpose, the sediment samples were sieved on $90 \mu \mathrm{m}$ sieves. The laboratory methods described by Brooks et al. [18] were used for the analysis. In total, 3503 specimens were identified and classified into three Chironomidae subfamilies and undetermined Ceratopogonidae. The subfossils were identified to the lowest possible 
taxonomic level, mainly using the keys of Brooks et al. [18] and Andersen et al. [93]. The sequence zonation was determined using the optimal sum-of-squares partitioning method described by Birks [94], Birks and Gordon [95], and Bennett [96]. The statistically significant number of zones was calculated based on the broken-stick model [97]. The number of zones was determined using ZONE software [98] and BSTICK [99], and the stratigraphic diagram was made using C2 software [100].

\subsubsection{Cladocera-Laboratory Techniques, Identification, and Statistics}

The sediments the Serteya STII M25 core were examined at 2-cm intervals. Each $1-\mathrm{cm}^{3}$ sample of the deposit was processed according to the standard procedure [101]. A minimum of 200 cladoceran remains per sample were identified. The taxonomy follows Szeroczyńska and Sarmaja-Korjonen [102] and Van Damm et al. [103]. The ecological preferences of cladoceran taxa were determined using Bjerring et al. [104]. The cladoceran zones were determined by a stratigraphically constrained cluster analysis (CONISS) using POLPAL software [105].

\subsubsection{Pollen—Laboratory Techniques, Identification, and Statistics}

A total of 55 one $\mathrm{cm}^{3}$ samples (2-cm interval) were treated following the standard pollen preparation procedures (treated with $\mathrm{HCl}$ and $\mathrm{NaOH}$, sieved using a 250- $\mu \mathrm{m}$ sieve, treated with HF, acetolysis) [106]. Pollen and NPPs were identified at a magnification of $\times 400$ and $\times 630$ with reference to published illustrations, morphological keys-including those of Fægri and Iversen [106], Reille [107], van Geel [108], van Geel and Aptroot [109], and Beug [110], and a laboratory reference collection. Pollen percentage and influx diagrams were constructed using Tilia software [111,112]. Aquatic and hygrophilous plants, undetermined pollen, ferns, moss, and NPPs were excluded from the pollen sum. The percentages of excluded taxa were calculated using the total pollen sum [113].

\subsection{Temperature, Precipitation, and Water Depth Reconstructions}

Climate parameters are inferred from chironomids, cladocerans, and pollen assemblages, and water level fluctuations are estimated using chironomids and cladoceran data. The characteristics of the training sets used are presented in Table 1.

Table 1. Training sets used in the analysis and their characteristics.

\begin{tabular}{|c|c|c|c|c|c|c|}
\hline Training Set & $\mathbf{R}^{2}$ jack & RMSEP & $\begin{array}{l}\text { Number } \\
\text { of Lakes }\end{array}$ & $\begin{array}{l}\text { Number } \\
\text { of Taxa }\end{array}$ & $\begin{array}{c}\text { Temperature/Water } \\
\text { Depth } \\
\text { Gradient }\end{array}$ & References \\
\hline $\begin{array}{c}\text { Finnish chironomid Training } \\
\text { Set Fn TS Ch-I T Jul }\end{array}$ & 0.86 & $0.85^{\circ} \mathrm{C}$ & 180 & 129 & $7.9^{\circ} \mathrm{C}-17.6^{\circ} \mathrm{C}$ & $\begin{array}{c}\text { Luoto and } \\
\text { Nevalainen } \\
\text { [114] }\end{array}$ \\
\hline $\begin{array}{c}\text { Swiss-Norwegian-Polish } \\
\text { chironomid Training Set SNP } \\
\text { TS Ch-I T Jul }\end{array}$ & 0.91 & $1.39^{\circ} \mathrm{C}$ & 357 & 134 & $3.5^{\circ} \mathrm{C}-20.1^{\circ} \mathrm{C}$ & $\begin{array}{l}\text { Kotrys et al } \\
2020[21]\end{array}$ \\
\hline $\begin{array}{l}\text { Russian chironomid Training } \\
\text { Set Rn TS Ch-I T Jul }\end{array}$ & 0.8 & $1.43^{\circ} \mathrm{C}$ & 310 & 172 & $1.8^{\circ} \mathrm{C}-18.8^{\circ} \mathrm{C}$ & $\begin{array}{l}\text { Nazarova } \\
\text { in prep. }\end{array}$ \\
\hline $\begin{array}{c}\text { Finish Cladocera Training Set } \\
\text { Fn TS CL-I T Jul }\end{array}$ & 0.67 & $0.86^{\circ} \mathrm{C}$ & 76 & 38 & $11.3^{\circ} \mathrm{C}-20.1^{\circ} \mathrm{C}$ & $\begin{array}{c}\text { Luoto et al. } \\
2011 \text { [115], } \\
\text { Nevalainen } \\
\text { et al. 2012 } \\
\text { [31] }\end{array}$ \\
\hline $\begin{array}{c}\text { Finnish Cladocera Depth } \\
\text { Training Set Fn TS CL-I depth }\end{array}$ & 0.56 & 1.084 & 55 & 56 & $0.5-7.0 \mathrm{~m}$ & $\begin{array}{l}\text { Luoto et al. } \\
2020[25]\end{array}$ \\
\hline
\end{tabular}

The pollen-inferred (P-I) reconstructions of temperature and precipitation at Serteya across the Holocene were performed using the Modern Analogue Technique (MAT) [116]. This method has been utilized at a global scale for samples from Europe $[117,118]$ and at a more regional scale for samples from Mediterranean pollen sequences [119,120]. The MAT is not a transfer function (cf. the WA-PLS) but an "assemblage approach," and is based on the primary assumption that pollen samples sharing a similar composition are 
a by-product of comparable vegetation assemblages. Using MAT, the composition and abundance of fossil pollen samples are compared with those of modern pollen surface samples, and the similarity between each fossil sample and modern pollen assemblage is evaluated by a squared chord distance.

Once a set of modern pollen samples has been selected as analogues (samples with the smallest distance), climate parameters are assigned to each fossil sample as the weighted average of the climate parameters of the modern samples which are the best analogues. In this study, the number of analogues chosen was five, which were selected using a leave-oneout cross-validation test. The training set of modern pollen samples contains more than 3000 samples from Europe and the Mediterranean area [76]. We also calculated and plotted the chord distance of the first best analogue (Distmin1) and the last analogue selected (Distmin2) (not illustrated) based on a threshold defined by a Monte Carlo method, in order to check the accuracy of the pollen-based climatic reconstruction. The minimum distance (Distmin1) calculated was low for P-I TCM, P-I AnP, indicating that the analogues selected are consistent. Based on previous studies, we reconstructed the climate for precipitation and mean TCM so that the results would be comparable across the region. These reconstructions were carried out using the package Rioja with R software [121].

A Detrended Correspondence Analysis (DCA) was carried out on the percentage data for the Chironomidae, Cladocera, and pollen datasets, with detrending by segments and down-weighting of rare species using Canoco 4.5 [122]. The temperature, water depth, and precipitation reconstructions used $\mathrm{C} 2$ and NeuroGenetic Optimizer software (NGO, version 2.6.130, ${ }^{\circledR}$ BioComp Systems, Inc.) $[100,123]$.

\section{Results and Interpretation}

\subsection{Chironomidae, Cladocera, and Pollen Assemblage Stratigraphy}

The detailed ecological description of the zones can be found in Kittel et al. [54], here we present only a summary of the ecological interpretation and diagrams (Figure S1). Based on the similarity analysis using CONISS and BSTICK [99,124], the zones are divided as follows for each proxy. The Chironomidae STII M25 sequence is divided into five significant zones (Figure S1, Figure 2) as follows: ST-Ch1 (158-146 cm b.g.l.), ST-Ch2 (146-131 cm b.g.l.), ST-Ch3 (131-100 cm b.g.l.), ST-Ch4 (100-89 cm b.g.l.), and ST-Ch5 (89-34 cm b.g.l.). The Cladocera sequence is divided into four zones (Figure S1, Figure 3) as follows: ST-Cl1 (158-150 cm b.g.l.), ST-Cl2 (150-78 cm b.g.1.), ST-Cl3 (78-44 cm b.g.l.), and ST-Cl4 (44-34 cm b.g.l.).

The pollen sequence is divided into two zones as follows: ST-P1 (150-100 cm b.g.l.) and ST-P2 (100-80 cm b.g.1.). The ST-P1 has four subzones: ST-P1a (150-138 cm b.g.l.), ST-P1b (138-128 cm b.g.l.), ST-P1c (128-117 cm b.g.l.), and ST-P1d (117-100 cm b.g.l.) (Figure S1, Figure 4). 


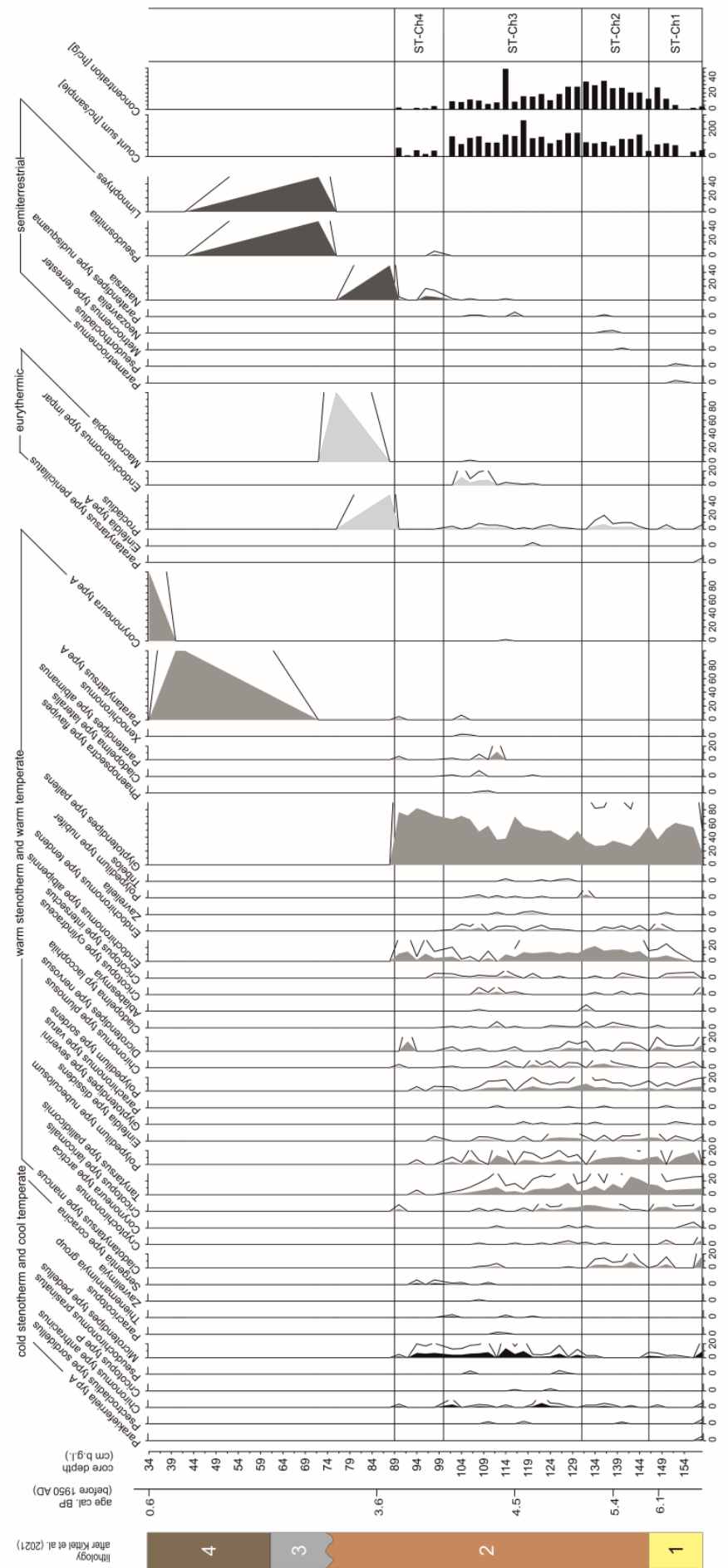

Figure 2. Chironomidae stratigraphic diagram presenting the main chironomid taxa. Taxa are grouped according to summer temperature and lake depth preferences. Exaggeration is with a three times multiplier. Lithology: 1-sand and gravel with organic mud and plant detritus; 2-coarse detritus gyttja; 3-carbonate sandy organic mud; 4-peaty organic mud with sandy admixtures. 


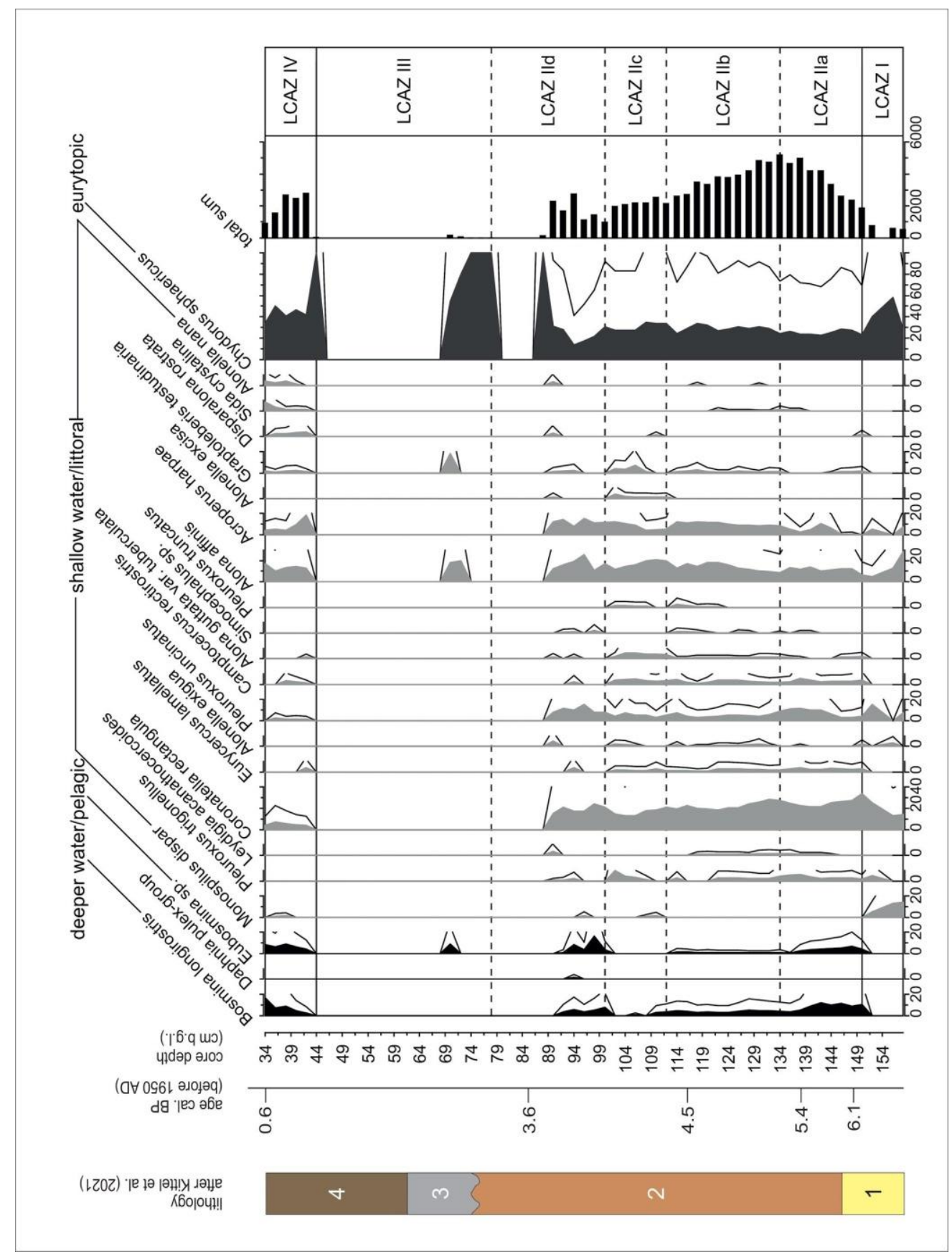

Figure 3. Cladocera stratigraphic diagram presenting the classification of taxa according to lake depth preferences. Exaggeration is with a three times multiplier. Lithology: 1—sand and gravel with organic mud and plant detritus; 2-coarse detritus gyttja; 3 - carbonate sandy organic mud; 4—peaty organic mud with sandy admixtures. 


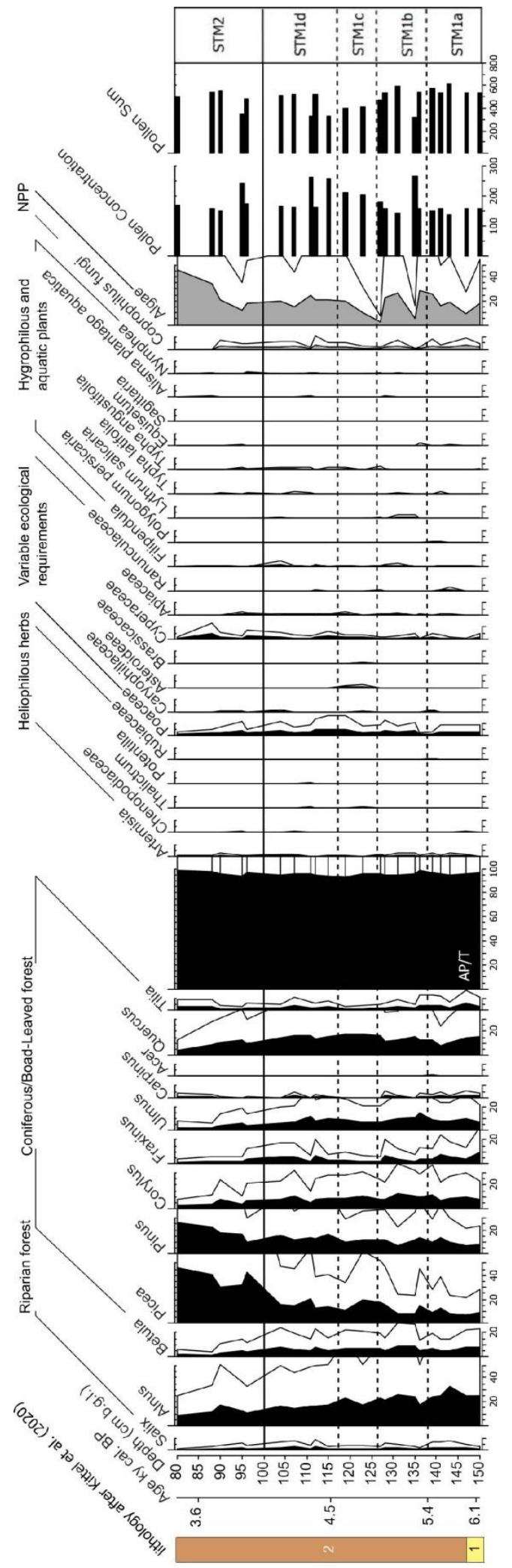

Figure 4. Pollen stratigraphic diagram. Exaggeration is with a three times multiplier. Lithology: 1 - sand and gravel with organic mud and plant detritus; 2 - coarse detritus gyttja. 


\subsection{Results and Interpretation of Climatic and Hydroclimatic Reconstructions}

4.2.1. Detrended Correspondence Analysis

The first DCA axis of the Chironomidae sequence explained $23.6 \%$ of the cumulative variance of species data and had a gradient length of 1.742, proving the linear distribution of the data. The second DCA axis explained $7.7 \%$ of the cumulative variance of species data. The DCA Ax1 of chironomid assemblages revealed a similar trend to the estimations of mean July air temperature from the Fn TS and SNP TS WA-PLS (Figure 5), which indicates that the summer temperature was the main driver of the midge communities. Furthermore, the estimations of mean July air temperature from the SNP TS artificial neural network (ANN) were similar to DCA Ax2 of Chironomidae assemblages, but it is a completely different trend than that marked on Ax1. The reconstruction based on the SNP of ANN reflects the influence of another unknown factor. Regarding Cladocera communities, the first DCA axis explained $27.3 \%$ of the cumulative variance of species data, with a gradient length of 1.339, proving the linear distribution of the data. The second DCA axis explained $9.9 \%$ of the cumulative variance. Similar to chironomid assemblages, the DCA Ax1 of cladoceran communities also reflected the mean July air temperature estimations from the Fn TS (Figure 5), indicating that the summer temperature was the main driver of the water flea communities, whereas Ax2 revealed a different trend.

4.2.2. The Chironomidae-Inferred and Cladocera-Inferred Mean Summer Air Temperature Reconstructions

According to the CH-I T Jul of the $31 \mathrm{Fn}$ TS samples, seven samples remained below the 2 percentile threshold $(\operatorname{minDC}<7.40328)$, representing that they are samples with very good modern analogues, 14 remained below the 5 percentile threshold ( $\operatorname{minDC}<8.85913$ ), representing good modern analogues, and only two had values over the 10 percentile threshold (minDC > 10.1025), representing poor or very poor modern analogues. Referring to the SNP TS WA-PLS reconstruction, among the 31 samples, only one was below the 2 percentile threshold (minDC $<6.98983$ ) and three were below the 5 percentile threshold ( $\operatorname{minDC}<8.57757)$, representing that they are samples with very good and good modern analogues, respectively. As many as 16 samples remained over the 10 percentile threshold (minDC $>10.0564)$, representing poor or very poor modern analogues. Regarding the $\mathrm{Rn}$ TS reconstruction, out of the 31 samples, two topmost ones were below the 5 percentile threshold (minDC < 36.57936), representing good modern analogues. Sixteen samples remained over the 10 percentile threshold ( $\operatorname{minDC}>40.72241$ ), representing poor and very poor modern analogues.

All the samples from the Cladocera-inferred (CL-I) T Jul Fn TS reconstruction represented very poor modern analogues $(\operatorname{minDC}>4.30013)$, falling over the 20 percentile threshold.

The values of Fn TS CH-I T Jul reconstruction varied from $16.3^{\circ} \mathrm{C}(158 \mathrm{~cm})$ to $20.9^{\circ} \mathrm{C}$ $(96 \mathrm{~cm})$ (Figure 5), SNP TS WA-PLS reconstruction from $15.9^{\circ} \mathrm{C}(142 \mathrm{~cm})$ to $21.3^{\circ} \mathrm{C}(96 \mathrm{~cm})$, and $\mathrm{Rn}$ TS reconstruction from $16.8^{\circ} \mathrm{C}(158 \mathrm{~cm})$ to $21.6^{\circ} \mathrm{C}(146 \mathrm{~cm})$. Generally, the Fn TS and SNP TS reconstructions revealed similar trends, but the SNP TS reconstruction showed a higher temperature amplitude and variability. Both reconstructions indicated an increase of summer temperature from the bottom to the top of the sequence, in two phases: the first, cooler phase $\left(158-126 \mathrm{~cm}\right.$ ) with an average CH-I T Jul of $17.2^{\circ} \mathrm{C}$ (SNP TS WA-PLS)-18.3 ${ }^{\circ} \mathrm{C}$ (Fn TS), and the second, warmer phase (124-94 cm) with an average $\mathrm{CH}-\mathrm{I} \mathrm{T}$ Jul of $18.9^{\circ} \mathrm{C}$ (Fn TS) $-19.0^{\circ} \mathrm{C}$ (SNP TS WA-PLS). The Rn TS reconstruction revealed a different trend, with a higher average temperature in the first phase $\left(19.5^{\circ} \mathrm{C}\right)$ and a slightly lower temperature in the second phase $\left(19.1^{\circ} \mathrm{C}\right)$. The weak cool oscillation took place at core depth $146-134 \mathrm{~cm}(6.0-5.75 \mathrm{ka}$ cal BP), culminating at $146-142 \mathrm{~cm}$. The temperature at the culmination of this episode was in the range $15.9-18.5^{\circ} \mathrm{C}$ (SNP TS WA-PLS), $18.4-19.1^{\circ} \mathrm{C}$ (Fn TS), and $18.4-21.6{ }^{\circ} \mathrm{C}$ (Rn TS). 


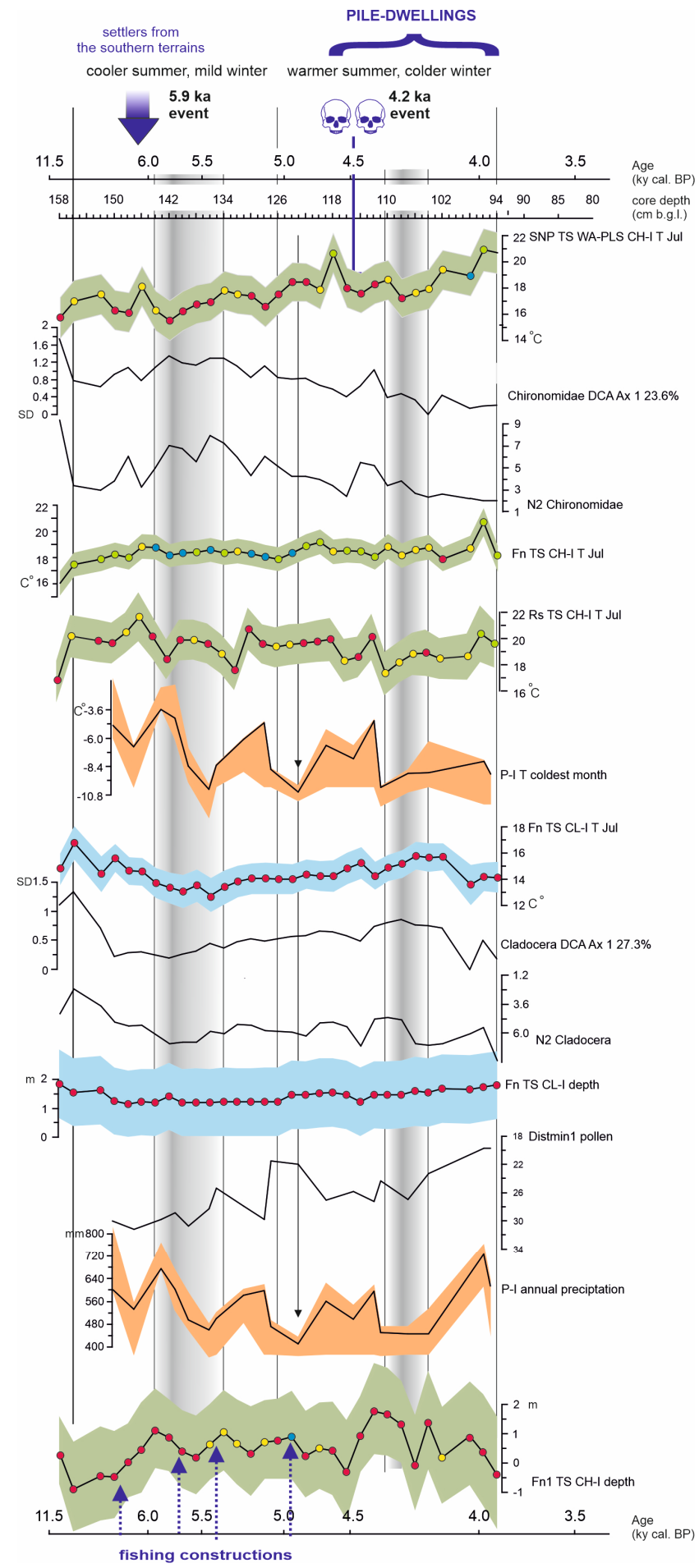

Figure 5. Results of quantitative climatic and water depth reconstructions: SNP TS WA-PLS CH-I T Jul; Chironomidae DCA Ax1 23.6\%; N2 Chironomidae (the number of occurrences of Chironomidae species); Fn TS CH-I T Jul; Rs TS CH-I T Jul; P-I TCM; Fn TS CL-I T Jul; Cladocera DCA Ax1 27.3\%; N2 Cladocera (the number of occurrences of Cladocera species); Fn TS CL-I depth; Distmin1 pollen (Euclidean distances calculated between the eight modern pollen assemblages considered as the best analogues and the fossil assemblage-nearest and furthest); P-I AnP; and Fn TS CH-I depth. Skulls with an arrow indicate the depth of the skeleton deposition. The arrows at 4.9 ka indicate peaks in precipitation and TCM (i.e., maximum continentality). 
The second small temperature decrease took place at core depth 120-94 cm (4.6-3.8 ka cal BP), culminating at 108-104 cm (4.3-4.1 ka cal BP). The temperature at the culmination of this episode was in the range of $17.6-18.3{ }^{\circ} \mathrm{C}$ (SNP TS WA-PLS), $18.2-18.9{ }^{\circ} \mathrm{C}$ (Rn TS), and $18.4-19.0^{\circ} \mathrm{C}$ (Fn TS). In the sample located directly at the skeleton deposition site $(115 \mathrm{~cm})$, there was no distinct change of the SNP TS and Fn TS mean summer temperature compared to the adjacent samples, but the Rn TS revealed a decrease of ca. $1.5^{\circ} \mathrm{C}$ at $114-116 \mathrm{~cm}$. The average CH-I T Jul for the period of the pile-dwelling location $(116-94 \mathrm{~cm})$ was $18.8^{\circ} \mathrm{C}$ (Fn TS, Rn TS) $-19.0{ }^{\circ} \mathrm{C}$ (SNP TS WA-PLS). The SNP TS ANN-based CH-I T Jul (not illustrated) revealed trends that are not consistent with the other mean summer temperature reconstructions for STII M25. Two clear phases were distinguished: the first with a rising temperature trend from $12.9^{\circ} \mathrm{C}(156 \mathrm{~cm})$ to $18.1^{\circ} \mathrm{C}(132 \mathrm{~cm})$, and the second with a temperature decline to $13.4-13.6{ }^{\circ} \mathrm{C}(104$ and $94 \mathrm{~cm})$.

The values of Fn TS CL-I T Jul reconstruction ranged from $12.9{ }^{\circ} \mathrm{C}(136 \mathrm{~cm})$ to $16.9{ }^{\circ} \mathrm{C}$ $(156 \mathrm{~cm})$ (Figure 5). The CL-I T Jul also revealed two phases, but they are not consistent with the Fn TS and SNP WA-PLS CH-I T Jul. The first phase was characterized by a clear decrease of temperature from $156 \mathrm{~cm} / 10.5 \mathrm{ka}$ cal BP $\left(16.9^{\circ} \mathrm{C}\right)$ to $136 \mathrm{~cm}\left(12.9^{\circ} \mathrm{C}\right)$, falling on the ca. 5.9-ka cal BP event. From that point on, there was a steady increase in temperature, up to $106-102 \mathrm{~cm} / \mathrm{ca} .4 .2-4.1 \mathrm{ka}$ cal BP $\left(15.8-15.9^{\circ} \mathrm{C}\right)$. During the 4.2-ka cal BP event, the summer temperature slightly decreased, reaching ca. $15.7^{\circ} \mathrm{C}$. In the case of the last three samples $(98-94 \mathrm{~cm})$, the summer temperatures inferred were lower again $\left(13.7-14.3^{\circ} \mathrm{C}\right)$. In the sample where the skeletons were located $(115 \mathrm{~cm})$, the mean summer temperature was $15.3{ }^{\circ} \mathrm{C}$ and slightly higher compared to the adjacent samples and the average CL-I T Jul for the period of the pile-dwelling location was $15.0^{\circ} \mathrm{C}$.

\subsubsection{The Pollen-Inferred Temperature of the Coldest Month and Annual Precipitation} Reconstructions

The P-I TCM values ranged from $-10.0{ }^{\circ} \mathrm{C}(123 \mathrm{~cm})$ to $-3.0{ }^{\circ} \mathrm{C}(143 \mathrm{~cm})$ (Figure 5), and P-I AnP values varied from $409 \mathrm{~mm}(123 \mathrm{~cm})$ to $725 \mathrm{~mm}(96 \mathrm{~cm})$. Both P-I reconstructions revealed a similar trend indicating phases of more continental (cold winter and arid years) and more Atlantic (mild winter and humid years) conditions. The reconstructions indicated a general decrease of P-I TCM and P-I AnP from the bottom to the top of the sequence. There were three alternate cold-winter and arid phases (Ic-141-135 cm; IIc-127-123 cm; IIIc-111-104 cm) and mild-winter and humid phases (Ia-150-141 cm; IIa-135-128 cm; IIIa-119-112 cm). The topmost samples from 96-95 cm revealed cold winters and high AnP. The cold-winter arid phase Ic fell on the 5.9-ka cal BP event and phase IIIc on the 4.2-ka cal BP event. Phase IIc coincided with a distinct rise of CH-I and CL-I summer temperature reconstructions derived from all three TSs. The minimum distance (Distmin1) calculated was low, indicating that the selected analogues are consistent and that our reconstruction is acceptable considering the possible bias due to the human impact on the pollen data. However, no indicator of farming activities was identified in the pollen diagram [57].

\subsubsection{The Cladocera-Inferred and Chironomidae-Inferred Lake Water Level} Reconstructions

All the samples of CL-I water depth reconstruction (CL-I depth) represented very poor modern analogues, which were over the 20 percentile threshold (minDC > 3.68913). According to the $\mathrm{CH}-\mathrm{I}$ water depth reconstruction (CH-I depth), only one sample from $124 \mathrm{~cm}$ remained below the 2 percentile threshold ( $\operatorname{minDC}<8.57652)$, representing very good modern analogues, and six remained within the 5-10 percentile threshold (9.81504 $<$ minDC < 10.8182), representing moderate modern analogues. All the other 24 samples remained over the 10 percentile threshold $(\operatorname{minDC}>10.8182)$, representing that they are samples with poor and very poor modern analogues.

The Fn TS CL-I depth reconstruction showed a constantly shallow littoral depth ranging from 1.2 to $2 \mathrm{~m}$. However, this reconstruction indicated a relative increase in water level at $142 \mathrm{~cm} / \mathrm{ca} .5 .9 \mathrm{ka}$ cal BP (from 1.2 to $1.5 \mathrm{~m}$ ) as well as at $96 \mathrm{~cm}$, where the highest water depth—ca. $2 \mathrm{~m}$-was recorded. In turn, at a depth of $114 \mathrm{~cm}$ (ca. $4.4 \mathrm{ka} \mathrm{cal} \mathrm{BP})$, the 
Fn TS CL-I depth showed a decrease of water level from 1.6 to $1.3 \mathrm{~m}$. The CL-I depth followed the general trend of the Fn TS and SNP TS WA-PLS CH-I T Jul, manifesting a lower average value for the first, cooler phase $(1.4 \mathrm{~m})$ and a slightly higher average value for the second, warmer phase $(1.6 \mathrm{~m})$. The $\mathrm{CH}-\mathrm{I}$ depth revealed four phases. At the Greenlandian (Preboreal-Early Atlantic) period, up to $6.1 \mathrm{ka}$ cal BP $(158-148 \mathrm{~cm})$, there was only astatic, possibly seasonal water inundation of the STII M25 site. At 146-142 cm falling on $6.0-5.75 \mathrm{ka}$ cal BP, i.e. the culmination of the 5.9-ka cal BP event, a clear transgression of the lake (increase from 0.4 to $1.1 \mathrm{~m}$ ) was observed, followed by a very shallow phase of occasional seasonal water conditions up to a core depth of $116 \mathrm{~cm}$ (average $\mathrm{CH}-\mathrm{I}$ depth $=$ $0.5 \mathrm{~m}$ ). The human bodies were deposited in astatic or seasonal water conditions at the horizon of ca. 115-cm core depth. From 114 to $98 \mathrm{~cm}$ of the core length, the second lake transgression to the average depth value of $1.2 \mathrm{~m}$ (excluding the $106 \mathrm{~cm}$ sample) took place, falling on the 4.2-ka cal BP event: 4.4-4.0 ka cal BP. At the topmost $96-94 \mathrm{~cm}$, low or even seasonal water conditions were recorded again. The average CH-I depth and CL-I depth for the period of the pile-dwelling location $(116-94 \mathrm{~cm}$ ) were 0.7 and $1.6 \mathrm{~m}$, respectively.

\section{Discussion}

The CH-I T Jul reconstructions were based on three different models. As the training sets originated from different regions-Western and Central Europe (SNP TS), Central and Northern Europe (Fn TS), and Eastern Eurasia (Rn TS), we obtained different results. Nonetheless, the reconstructions were consistent, giving similar values and showing more or less similar trends. It is not surprising that the SNP TS and Fn TS showed similar trends compared to the more dissimilar Rn TS, because they shared ca. 100 sites from Poland. The SNP TS revealed high temperature variability because it combines three different climatic regions representing separate midge fauna, with a wide range of temperatures. The Fn TS gave the closest modern analogues as it uses samples from the nearby geographical region. The results of the Fn TS reconstruction are strongly flattened. The Rn TS gave the highest temperature values, in the range of continental climates of Central Siberia. This reconstruction indicates an overall slightly decreasing trend, but is erratic. The DCA and N2 showed similar trends to the SNP TS reconstruction indicating that the summer temperature was a dominant driver for Chironomidae communities. The cold oscillations took place at about 5.9 and $4.2 \mathrm{ka}$. Generally, these oscillations are weak and are apparent in a few consecutive samples (1-4) and indicate a drop in T Jul of ca. $1-2{ }^{\circ} \mathrm{C}$. This exceeds the RMSEP of the models, which suggests this is not noise. It can be seen from the reconstructions that during the Northgrippian stage the summer air temperature was high, mostly in the range of $17-20^{\circ} \mathrm{C}$. These values are similar to the current July air temperatures in the Serteya region $[80,125]$. A comparison with other sites in Eastern Europe indicates that the values of P-I TWM and CH-I T Jul were usually $2{ }^{\circ} \mathrm{C}$ lower in the circum-Baltic region, whereas on the Central Polish Plain (e.g., Żabieniec, Błędowo) and the Central Russian Plain (Staroselsky Moch, Peatland Klukva) the values were similar to those at the Serteya STII M25 (Table S1, Figure S2). The data from the Leningrad Oblast shows a cold oscillation between 5.9 and $4.2 \mathrm{ka}$ cal BP [43]. This result indicates that in more continental regions, distant from the Baltic influence, the summer temperatures were slightly higher.

The SNP TS reconstructions showed a increasing temperature trend from 5.9 to $4.2 \mathrm{ka}$ cal BP, punctuated by two cool oscillations indicated at 5.9 and $4.2 \mathrm{ka}$. However, the $\mathrm{Rn}$ TS showed a weakly decreasing trend. An increasing trend is also indicated from Upper Don [45]. The global temperature trend of terrestrial records from $30^{\circ}$ to $60^{\circ}$ latitude is decreasing after $6 \mathrm{ka}$ cal BP [126,127]. In addition, the simulations of Renssen et al. [128] indicated that the Holocene Thermal Maximum (HTM) occurred in Eastern Europe earlier than $6 \mathrm{ka}$ cal BP. A comparison of the temperature of both cooling events in Table S1 indicated a similar trend in the East European Lowland. At some sites in the southern part of the region, the temperatures were slightly higher at $5.9 \mathrm{ka}$ cal BP. However, in the northern part, some sites had slightly higher TWM during $4.2 \mathrm{ka}$ cal BP. Warden et al. [3] clearly indicated that the HTM in the pari-Baltic region occurred at ca. 5.9-5.5 ka cal BP, 
with a cooling trend to $4.2 \mathrm{ka}$ cal BP. The nearby P-I TWM reconstruction from Staroselsky Moch revealed more or less the same values through 6-4 ka cal BP. Tarasov et al. [62] also suggested that in the Western Dvina Lakeland HTM occurred in ca 8.6-6.9 ka cal BP and in the Karelian Isthmus in ca $7.8 \mathrm{cal} \mathrm{BP} \mathrm{[40].} \mathrm{It} \mathrm{started} \mathrm{and} \mathrm{ended} \mathrm{some} \mathrm{centuries} \mathrm{earlier} \mathrm{than}$ suggested for the neighboring Baltic region-ca 8.1-5.6 ka cal BP. Based on pollen data, Tarasov et al. [62] reported that the climate in Middle Holocene was dryer and warmer, whereas after $5.4 \mathrm{ka}$ cal BP the climate was cooler and wetter. Nonetheless, the authors did not perform quantitative reconstructions from the investigated sites, but their results seem to be more consistent with the Rn TS reconstruction.

The SNP TS and Fn TS revealed a cold oscillation from the Mid- to Late Northgrippian (5.9-4.2 ka cal BP) stage. It may be a microclimate pattern that is dependent on local factors such as lake transgressions. The warm-stenotherm chironomid taxa usually have preferences for a higher trophic state [17]. Human-induced eutrophication might have overridden the influence of July air temperature resulting in higher reconstructed temperatures [57].

Juggins [129] suggested that only one quantitative reconstruction should be obtained from a particular proxy. Here, we decided to illustrate both reconstructions from the pollen data. Both revealed very similar trends and were consistent with Distmin1 (Figure 5). This suggests that plant communities were influenced by one climatic factor: continentality fluctuations. Such a coincidence of decreased precipitation and TCM indicates that continentality is the main driving factor of plant communities in the region. At about $4.9 \mathrm{ka}$ occurs sudden drop in precipitation and TCM. The values of TCM, TWM/T Jul, and AnP were compared for a wide group of 22 sites from Eastern Europe (Table S1), no clear signal of the 5.9- and 4.2-ka cal BP oscillations in the region was noted.

Knowledge about the cold episode at ca $5.9 \mathrm{ka}$ BP is still insufficient. There is no consensus on the magnitude and timing of the 5.9 Bond event oscillation in eastern Europe [36,128-131]. This raises a doubt whether there are any well-documented quantitative reconstructions of these Bond events in Eastern Europe. Where there are some records indicating oscillations in a few consecutive samples, the signal is weak and unclear. Hence, climatic records of much better resolution are needed from the region to verify the hypothesis of the presence of these Bond events.

Because the Bond events are linked to the NAO fluctuations, they might be more significant in Western Europe than in the East. The European territory along the North Atlantic is the main area to be affected by this climatic phenomenon. The STII M25 site is located in the Western Dvina Lakeland in the contact zone of transitional and continental climate, which could have made it sensitive to the paleoclimatic regime changes (NAO circulation). Based on their studies, Yao and Luo [130] and Rousi et al. [131] concluded that the eastern and western types of NAO differently influence the temperature and precipitation regimes in Europe. To study the magnitude of the NAO influence and the relationship between NAO and the temperate climate zone, the domain size must also be considered [132]. For this zone, the optimal domain sizes are lower in summer compared to winter, and for continental rather than oceanic regions. The NAO will likely have a stronger impact on the climate of Northeast Europe in winter in continental regions. From the results (Figure 5), one can speculate that the positive NAO phases during the 4.2 and 5.9 ka events was characterized by cool summers and severely cold winters, as well as intense precipitation mostly in autumn. The differences between the dynamics of precipitation during these events may result from changes in the activity of ultraviolet radiation and glacier size. For further conclusions, it is necessary to study more sites in Eastern Europe at high temporal resolution. However, for the LIA, correlated with the Bond Event no. 0, a predominance of negative NAO phases is postulated by Trouet [133]. Moreover, a positive NAO phase is postulated for the MCA-LIA period [134,135]. It must be also stressed that Moreno-Chamarro et al. [136] emphasis a reduction in the heat transport by the subpolar gyre rather than a NAO impact on the LIA cooling, mostly during the winter seasons. 
The boundary of boreal plant assemblages and temperate deciduous forest in the studied area also reflect the climate zones. Thus, P-I reconstructions should reflect the change in the range of vegetation composition in Eastern Europe. Pleskot et al. [137] questions the presence of the 4.2-ka cal BP oscillation in Poland. At the STII M25 P-I, the higher continentality signal is clear at both events and has also been recorded in a few subsequent samples. Pleskot et al. [137] performed only CH-I T Jul reconstruction. The STII M25 CH-I T Jul reconstruction also gave a weak and ambiguous signal of 4.2- and 5.9-ka cal BP oscillations. P-I reconstructions revealed a much clearer pattern at the STII M25 site, but not at the nearby Staroselsky Moch and Klukva Peatland [138,139].

The P-I TCM/AnP and CH-I T Jul reconstructions from STII M25 indicated the third intermediate oscillation falling on 5.0-4.7 ka cal BP. This oscillation manifests by a small increase of T Jul at $5.1 \mathrm{ka}$ and distinct increase in continentality. Its maximum effect falls on 4.9-4.8 ka cal BP, and its magnitude is comparable with the 5.9-ka cal BP signal and stronger than the 4.2-ka cal BP one. Modern maps indicate that this microregion differs from the wider Smolensk region. The oscillation may have had a more local character as there are warmer and colder microregions within the Western Dvina Lakeland. Besides P-I and CH-I, the present study performed CL-I summer temperature and lake depth reconstructions. Although water level fluctuations are regarded as the primary factor influencing Cladocera communities in the long term [28], the DCA (Figure 5) results were consistent with the CL-I summer temperature reconstruction, indicating it as the primary driver of cladoceran communities. The values of temperature are lower than $\mathrm{CH}-\mathrm{I} \mathrm{T}$ Jul because midges are more linked to air temperature while water fleas are linked to water temperature $[6,24,140,141]$. Thus, the lower values of CL-I temperature are not surprising; however, the decrease of CL-I T Jul also differs from CH-I. From 136 to $104 \mathrm{~cm}$ b.g.l., the temperature increasing was observed, similar to the SNP and Fn TS CH-I T Jul reconstructions, although the earlier (158-134 cm b.g.1.) oscillation was opposite. In addition, the reconstruction from the three topmost samples revealed a dissimilar pattern to all $\mathrm{CH}-\mathrm{I}$ reconstructions. This can also be explained by the differences and complexity of proxy responses to temperature which merges with water trophic state and other environmental factors [142]. Moreover, it needs to be mentioned that CL-I reconstructions from STII M25 gave poor and very poor modern analogues.

Finally, the question of $\mathrm{CH}-\mathrm{I}$ water level reconstruction remains. Because the site is located in the lakeshore zone $[57,85]$, water level fluctuations at STII M25 are crucial for explaining the environmental causes of Neolithic settlements. The results showed by CL-I and $\mathrm{CH}-\mathrm{I}$ lake depth reconstructions are consistent with general observations that STII M25 is located in the shallow littoral zone [57]. The CH-I lake depth suggests that the water level was unstable and may have even been seasonal before the 5.9-ka cal BP event, and then there were very shallow water conditions up to ca. $4.5 \mathrm{ka}$ cal BP. According to the CH-I lake depth, the bodies of women recovered at ca. $115 \mathrm{~cm}$ b.g.l. should have been placed when the water level was increasing before the 4.2-ka cal BP event. During this event, the lake revealed a higher water level than during the 5.9-ka cal BP event. Nonetheless, the CH-I depth gave generally better modern analogues between the 5.9- and 4.2-ka cal BP event in comparison to the CL-I depth, and the fluctuations of both reconstructions remained within the RMSEP range. The mean July temperature was the leading factor in the case of both Chironomidae and Cladocera, overriding water level fluctuations in the permanently shallow littoral zone. Therefore, the constructed quantitative reconstructions of water level fluctuations are doubtful, and in this case, qualitative reconstructions of the habitat change presented in a previous study [57] are more valid.

The above-presented reconstructions prove that climate conditions during the Northgrippian stage were suitable for human communities. The local microclimate in the Serteya could have been buffered by the lake-river system, weakening the fluctuations of summer temperature during 5.9 and $4.2 \mathrm{ka}$ cal BP. Summer temperature was relatively high during the whole Northgrippian stage, due to which tribes from the Black Sea Lowland settled here after $8.2 \mathrm{ka}$ cal BP $[1,55]$. Stable climate conditions would imply constant primary and 
secondary production of an ecosystem supporting a hunter-gatherer economy for a long time after agricultural development in localities in the West and the North [3]. However, plant communities here consist of those that clearly reacted negatively to the 5.9- and 4.2-ka cal BP event. This suggests that the Bond events might have indeed influenced the ecology of local settlers triggering a change in their culture to altered, more difficult (higher continentality) conditions. The intermediate climate oscillation falling on 5.0-4.7 ka cal BP coincides with the appearance of relicts of the Globular Amphora culture at the Serteyka River Valley. It indicates that local settlers participated in spreading trails of amber to the East. Hence, the Western Dvina Lakeland must have had high economic status in the region $[57,85]$ which can be attributed to productive local ecosystems, high geodiversity, and favorable [142] climate conditions.

\section{Conclusions}

In recent years, quantitative reconstructions have impacted paleoecology mainly by providing precise quantitative records, though they have their own limitations. One of them is the reconstructed chronology of non-laminated lake sediments, another is sedimentation rate in lakes, and the lag in the reaction of plant biota to climate change that limits reconstruction to decadal resolution [143]. Moreover, the methods used for quantitative reconstructions have their own statistical limitations which can be accessed from the R2, RMSEP, and modern analogues. The climatic records may be obscured by local impacts from non-climatic influences on the proxies $[129,142]$. The present study has included several reconstructions using three different proxies: chironomids, cladocerans, and pollen. Summer mean air temperature appeared to have a stronger influence than the lake depth on the midges and water fleas, which is in line with the general observations of their ecology $[144,145]$. This indicates that local water level fluctuations had only a secondary effect on the littoral lake ecosystem. The CH-I mean air temperature and CL-I mean water temperature of the summer season are similar to the recent, Late Holocene values. Although STII M25 is located in the western part of the archaeological site, not within a major dwelling area of the pile-dwelling settlement, human-induced local eutrophication might have still reinforced the effect of temperature, to produce a false signal of temperature increase inferred from Chironomidae as well as Cladocera. The pollen analysis indicated an increase in continentality during the investigated period. Furthermore, P-I TCM and AnP showed clearer oscillations at the 5.9- and 4.2-ka cal BP events than the chironomids and Cladocera. Hence, the P-I reconstructions may be considered as the primary result of the presented studies. It is difficult to recognize mid-Holocene (Northgrippian) oscillations, especially in Eastern Europe where the influence of NAO is weaker $[24,69,137]$. In order to speculate about their time shift (5.9 $\mathrm{ka}$ cal BP and $4.2 \mathrm{cal} \mathrm{BP}$ ), it would be useful to increase the number of quantitative reconstructions for the area of Eastern Europe. The comparison of the results obtained with broad-spectrum quantitative reconstructions from the region (Table S1) shows that the SNP TS results do agree with other global reconstructions. Most reconstructions from Eastern Europe have insufficient resolution to capture Bond oscillations in the Northgrippian stage. Considering all the methodological cautions in the interpretation of the presented results, we are inclined to support the alternative hypothesis presented in the Introduction, though with some reservations. Nevertheless, we cannot prove that the oscillations are at a regional or global scale and result from NAO. We assume that these climate changes might have influenced the progression of the Serteya II settlement over time, including the possible collapse of the pile-dwelling settlement at $4.2 \mathrm{ka}$ cal BP and the prolonged existence of a hunter-fisher-gatherer subsistence strategy as the conditions were favorable for the productivity of local ecosystems.

Supplementary Materials: The following are available online at https:/ /www.mdpi.com/article/ 10.3390/w13111611/s1, Table S1. Review of quantitative climatic and water level reconstructions from the region in $5.9 \mathrm{ka}$ cal BP and $4.2 \mathrm{ka}$ cal BP. Part of the records is based on Kaufman et al. (2020) [146-160]: http://lipdverse.org/Temp12k/current_version/. Data access: 1 January 2021; Figure S1. Zonation of Cladocera, Chironomidae, and pollen communities based on Kittel et al. 2021. 
Lithology: 4-peaty organic mud with sandy admixtures; 3-carbonate sandy organic mud, 2-coarse detritus gyttja, 1-sand and gravel with organic mud and plant detritus; Figure S2. Map of sites mentioned in Table S1.

Author Contributions: A.M. (Agnieszka Mroczkowska) conducted the Chironomidae analysis, proposed the idea of the main text, constructed the manuscript, and contributed to the figures. D.P. conducted the Cladocera analysis, and contributed to the main text and figures. E.G. and E.T. conducted the pollen analysis, and contributed to the main text and figures. A.M. (Andrey Mazurkevich) and E.V.D. conducted the archaeological field research, and contributed to the main text and the concept of paleoecological studies at the STII site. T.P.L. conducted the climatic and hydrological reconstructions from the Fn TS and East European TSs. O.P. conducted the pollen climatic reconstructions. B.K. conducted the climatic reconstruction from the SNP TS and contributed to the field investigation at the STII site. S.J.B. conducted the climatic reconstruction from the SNP TS. L.B.N. conducted the climatic reconstruction from the Rs TS. L.S. conducted the climatic reconstruction from the Rs TS. DE conducted field research at the STII site. E.T. conducted the pollen analysis. M.P. provided comments to the manuscript, statistics, and figures. O.A.-O. contributed to the main text. P.K. is the head of the project, invented the concept of paleoclimatic and paleoecological studies at the STII site, conducted paleoenvironmental field research at the site, and contributed to the main text and figures. All authors have read and agreed to the published version of the manuscript.

Funding: The author(s) disclosed receipt of the following financial support for the research, authorship, and/or publication of this article: This research was supported by grants 2017/25/B/HS3/00274 and 2018/31/B/ST10/02498 from the National Science Center (Poland). N.L. was supported by the Russian Scientific Foundation, grant 20-17-00135.

Institutional Review Board Statement: Not applicable.

Informed Consent Statement: Not applicable.

Data Availability Statement: The data presented in this study are available on request from the corresponding author.

Conflicts of Interest: The authors declare no conflict of interest.

\section{References}

1. Sánchez Goñi, M.F.; Ortu, E.; Banks, W.E.; Giraudeau, J.; Leroyer, C.; Hanquiez, V. The expansion of Central and Northern European Neolithic populations was associated with a multi-century warm winter and wetter climate. Holocene 2016, 26, 1188-1199. [CrossRef]

2. Kulkova, M.; Mazurkevich, A.; Dolbunova, E.; Lozovsky, V. The 8200 calBP climate event and the spread of the Neolithic in Eastern Europe. Doc. Praehist. 2015, 42, 77-92. [CrossRef]

3. Warden, L.; Moros, M.; Neumann, T.; Shennan, S.; Timpson, A.; Manning, K.; Sollai, M.; Wacker, L.; Perner, K.; Häusler, K. Climate induced human demographic and cultural change in northern Europe during the mid-Holocene. Sci. Rep. 2017, 7, 15251. [CrossRef] [PubMed]

4. Kaufman, D.; McKay, N.; Routson, C.; Erb, M.; Davis, B.; Heiri, O.; Jaccard, S.; Tierney, J.; Dätwyler, C.; Axford, Y. A global database of Holocene paleotemperature records. Sci. Data 2020, 7, 115. [CrossRef]

5. Khomutova, V.I.; Elina, G.A. Stratigraphy of lake sediments by palynological data. Istoria Ladozhskogo, Onezhskogo, PskovskoChudskogo ozer, Baikala i Khanki [The history of Ladoga, Onego, Pskovsko-Chudskoe, Baikal and Khanki lakes]. 1990. pp. 92-96.

6. Elina, G.; Filimonova, L.; Raukas, A.; Saarse, L. Late-Glacial Vegetation on the Territory of Karelia. In Palaeohydrology of the Temperate Zone III: Mires and Lakes; Valgus: Tallinn, Estonia, 1987; pp. 53-69.

7. Nazarova, L.; Syrykh, L.S.; Mayfield, R.J.; Frolova, L.A.; Ibragimova, A.G.; Grekov, I.M.; Subetto, D.A. Palaeoecological and palaeoclimatic conditions on the Karelian Isthmus (northwestern Russia) during the Holocene. Quat. Res. 2020, 95, 65-83. [CrossRef]

8. Nazarova, L.B.; Subetto, D.A.; Syrykh, L.S.; Grekov, I.M.; Leontev, P.A. Reconstructions of Paleoecological and Paleoclimatic Conditions of the Late Pleistocene and Holocene according to the Results of Chironomid Analysis of Sediments from Medvedevskoe Lake (Karelian Isthmus). Dokl. Earth Sci. 2018, 480, 710. [CrossRef]

9. Feurdean, A.; Perşoiu, A.; Tanţău, I.; Stevens, T.; Magyari, E.K.; Onac, B.P.; Marković, S.; Andrič, M.; Connor, S.; Fărcaş, S. Climate variability and associated vegetation response throughout Central and Eastern Europe (CEE) between 60 and 8 ka. Quat. Sci. Rev. 2014, 106, 206-224. [CrossRef] 
10. Moreno, A.; Svensson, A.; Brooks, S.J.; Connor, S.; Engels, S.; Fletcher, W.; Genty, D.; Heiri, O.; Labuhn, I.; Perşoiu, A. A compilation of Western European terrestrial records 60-8 ka BP: Towards an understanding of latitudinal climatic gradients. Quat. Sci. Rev. 2014, 106, 167-185. [CrossRef]

11. Berntsson, A.; Rosqvist, G.C.; Velle, G. Late-Holocene temperature and precipitation changes in Vindelfjällen, mid-western Swedish Lapland, inferred from chironomid and geochemical data. Holocene 2014, 24, 78-92. [CrossRef]

12. Heinsalu, A.; Veski, S. The history of the Yoldia Sea in Northern Estonia: Palaeoenvironmental conditions and climatic oscillations. Geol. Q. 2007, 51, 295-306.

13. Kremenetski, K.; Borisova, O.; Zelikson, E. The Late Glacial and Holocene history of vegetation in the Moscow region. Paleontol. J. C/C Paleontol. Zhurnal 2000, 34, 67-74.

14. Sapelko, T.V. Dinamika razvitiâ rastitel'nosti na territorii Kenozerskogo nacional'nogo parka v golocene. Izv. Rus. Geogr. Obŝestva 2006, 138, 70-76.

15. Velichko, A.A.; Andreev, A.; Klimanov, V. Climate and vegetation dynamics in the tundra and forest zone during the Late Glacial and Holocene. Quat. Int. 1997, 41, 71-96. [CrossRef]

16. Velichko, A.A.; Catto, N.; Drenova, A.N.; Klimanov, V.A.; Kremenetski, K.V.; Nechaev, V.P. Climate changes in East Europe and Siberia at the Late glacial-holocene transition. Quat. Int. 2002, 91, 75-99. [CrossRef]

17. Kołaczek, P.; Karpińska-Kołaczek, M.; Marcisz, K.; Gałka, M.; Lamentowicz, M. Palaeohydrology and the human impact on one of the largest raised bogs complex in the Western Carpathians (Central Europe) during the last two millennia. Holocene 2018, 28, 595-608. [CrossRef]

18. Brooks, S.J.; Heiri, O.; Langdon, P.G. The Identification and Use of Palaearctic Chironomidae Larvae in Palaeoecology; Quaternary Research Association: London, UK, 2007.

19. Oliver, D. Life history of the Chironomidae. Annu. Rev. Entomol. 1971, 16, 211-230. [CrossRef]

20. Eggermont, H.; Heiri, O. The chironomid-temperature relationship: Expression in nature and palaeoenvironmental implications. Biol. Rev. 2012, 87, 430-456. [CrossRef]

21. Kotrys, B.; Płóciennik, M.; Sydor, P.; Brooks, S.J. Expanding the Swiss-Norwegian chironomid training set with Polish data. Boreas 2020, 49, 89-107. [CrossRef]

22. Magny, M.; Combourieu-Nebout, N.; De Beaulieu, J.-L.; Bout-Roumazeilles, V.; Colombaroli, D.; Desprat, S.; Francke, A.; Joannin, S.; Ortu, E.; Peyron, O. North-south palaeohydrological contrasts in the central Mediterranean during the Holocene: Tentative synthesis and working hypotheses. Clim. Past 2013, 9, 2043-2071. [CrossRef]

23. Frolova, L.; Nazarova, L.; Pestryakova, L.; Herzschuh, U. Analysis of the effects of climate-dependent factors on the formation of zooplankton communities that inhabit arctic lakes in the Anabar River Basin. Contemp. Probl. Ecol. 2013, 6, 1-11. [CrossRef]

24. Płóciennik, M.; Pawłowski, D.; Vilizzi, L.; Antczak-Orlewska, O. From oxbow to mire: Chironomidae and Cladocera as habitat palaeoindicators. Hydrobiologia 2020, 847, 3257-3275. [CrossRef]

25. Luoto, T.P.; Kivilä, E.H.; Kotrys, B.; Płóciennik, M.; Rantala, M.V.; Nevalainen, L. Air temperature and water level inferences from northeastern Lapland (69 N) since the Little Ice Age. Pol. Polar Res. 2020, 23-40. [CrossRef]

26. Pawłowski, D.; Płóciennik, M.; Brooks, S.J.; Luoto, T.P.; Milecka, K.; Nevalainen, L.; Peyron, O.; Self, A.; Zieliński, T. A multiproxy study of Younger Dryas and Early Holocene climatic conditions from the Grabia River paleo-oxbow lake (central Poland). Palaeogeogr. Palaeoclimatol. Palaeoecol. 2015, 438, 34-50. [CrossRef]

27. Pawłowski, D.; Kowalewski, G.; Milecka, K.; Płóciennik, M.; Woszczyk, M.; Zieliński, T.; Okupny, D.; Włodarski, W.; Forysiak, J. A reconstruction of the palaeohydrological conditions of a flood-plain: A multi-proxy study from the Grabia River valley mire, central Poland. Boreas 2015, 44, 543-562. [CrossRef]

28. Nevalainen, L.; Sarmaja-Korjonen, K.; Luoto, T.P. Sedimentary Cladocera as indicators of past water-level changes in shallow northern lakes. Quat. Res. 2011, 75, 430-437. [CrossRef]

29. Pawłowski, D.; Borówka, R.K.; Kowalewski, G.; Luoto, T.P.; Milecka, K.; Nevalainen, L.; Okupny, D.; Płóciennik, M.; Woszczyk, M.; Tomkowiak, J. The response of flood-plain ecosystems to the Late Glacial and Early Holocene hydrological changes: A case study from a small Central European river valley. Catena 2016, 147, 411-428. [CrossRef]

30. Pawłowski, D.; Borówka, R.K.; Kowalewski, G.A.; Luoto, T.P.; Milecka, K.; Nevalainen, L.; Okupny, D.; Tomkowiak, J.; Zieliński, T. Late Weichselian and Holocene record of the paleoenvironmental changes in a small river valley in Central Poland. Quat. Sci. Rev. 2016, 135, 24-40. [CrossRef]

31. Nevalainen, L.; Luoto, T.P.; Kultti, S.; Sarmaja-Korjonen, K. Do subfossil Cladocera and chydorid ephippia disentangle Holocene climate trends? Holocene 2012, 22, 291-299. [CrossRef]

32. Pawłowski, D. Younger Dryas climatic reconstructions in central Poland. Acta Geol. Pol. 2017, 67, 567-584. [CrossRef]

33. Marcisz, K.; Gałka, M.; Pietrala, P.; Miotk-Szpiganowicz, G.; Obremska, M.; Tobolski, K.; Lamentowicz, M. Fire activity and hydrological dynamics in the past 5700 years reconstructed from Sphagnum peatlands along the oceanic-continental climatic gradient in northern Poland. Quat. Sci. Rev. 2017, 177, 145-157. [CrossRef]

34. Gałka, M.; Miotk-Szpiganowicz, G.; Marczewska, M.; Barabach, J.; van der Knaap, W.O.; Lamentowicz, M. Palaeoenvironmental changes in Central Europe (NE Poland) during the last 6200 years reconstructed from a high-resolution multi-proxy peat archive. Holocene 2015, 25, 421-434. [CrossRef] 
35. Lamentowicz, M.; Lamentowicz, Ł.; van der Knaap, W.O.; Gabka, M.; Mitchell, E.A.D. Contrasting Species—Environment Relationships in Communities of Testate Amoebae, Bryophytes and Vascular Plants Along the Fen-Bog Gradient. Microb. Ecol. 2010, 59, 499-510. [CrossRef] [PubMed]

36. Heikkilae, M.E.; Seppä, H. Holocene climate dynamics in Latvia, eastern Baltic region: A pollen based summer temperature reconstruction and regional comparison. Boreas 2010, 39, 705-719. [CrossRef]

37. Sohar, K.; Kalm, V. A 12.8-ka-long palaeoenvironmental record revealed by subfossil ostracod data from lacustrine freshwater tufa in Lake Sinijärv, northern Estonia. J. Paleolimnol. 2008, 40, 809-821. [CrossRef]

38. Šeirienè, V.; Kabailienè, M.; Kasperovičienè, J.; Mažeika, J.; Petrošius, R.; Paškauskas, R. Reconstruction of postglacial palaeoenvironmental changes in eastern Lithuania: Evidence from lacustrine sediment data. Quat. Int. 2009, 207, 58-68. [CrossRef]

39. Stivrins, N.; Kalnina, L.; Veski, S.; Zeimule, S. Local and regional Holocene vegetation dynamics at two sites in eastern Latvia. Boreal Environ. Res. 2014, 19, 310-322.

40. Terasmaa, J.; Puusepp, L.; Marzecová, A.; Vandel, E.; Vaasma, T.; Koff, T. Natural and human-induced environmental changes in Eastern Europe during the Holocene: A multi-proxy palaeolimnological study of a small Latvian lake in a humid temperate zone. J. Paleolimnol. 2013, 49, 663-678. [CrossRef]

41. Syrykh, L.; Subetto, D.; Nazarova, L. Paleolimnological studies on the East European Plain and nearby regions: The PaleoLake Database. J. Paleolimnol. 2021, 65, 369-375. [CrossRef]

42. Subetto, D.; Nazarova, L.; Pestryakova, L.; Syrykh, L.; Andronikov, A.; Biskaborn, B.; Diekmann, B.; Kuznetsov, D.; Sapelko, T.; Grekov, I. Paleolimnological studies in Russian northern Eurasia: A review. Contemp. Probl. Ecol. 2017, 10, 327-335. [CrossRef]

43. Arslanov, K.A.; Savelieva, L.; Klimanov, V.; Chernov, S.; Maksimov, F.; Tertychnaya, T.; Subetto, D. New data on chronology of landscape-paleoclimatic stages in Northwestern Russia during the Late Glacial and Holocene. Radiocarbon 2001, $43,581-594$. [CrossRef]

44. Novik, A.; Punning, J.-M.; Zernitskaya, V. The development of Belarusian lakes during the Late Glacial and Holocene. Est. J. Earth Sci. 2010, 59, 63-79. [CrossRef]

45. Novenko, E.; Glasko, M.; Volkova, E.; Ziuganova, I. Dinamika landšaftov i klimata bassejna verhnego Dona v srednem i pozdnem golocene. Izvestiâ Akademii nauk SSSR. Seria geografičeskaâ 2013, 2, 68-82.

46. Arslanov, K.A.; Saveljeva, L.; Gey, N.; Klimanov, V.; Chernov, S.; Chernova, G.; Kuzmin, G.; Tertychnaya, T.; Subetto, D.; Denisenkov, V. Chronology of vegetation and paleoclimatic stages of northwestern Russia during the Late Glacial and Holocene. Radiocarbon 1999, 41, 25-45. [CrossRef]

47. Nazarova, L.; Herzschuh, U.; Wetterich, S.; Kumke, T.; Pestryakova, L. Chironomid-based inference models for estimating mean July air temperature and water depth from lakes in Yakutia, northeastern Russia. J. Paleolimnol. 2011, 45, 57-71. [CrossRef]

48. Nazarova, T.; Fomin, I.; Dmitriev, P.; Wendt, J.; Janaleyeva, K. Landscape and limnological research of lake systems of the northeastern borderlands of the Republic of Kazakhstan and assesment of their recreational capacity. Geoj. Tour. Geosites 2019, 25, 485-495. [CrossRef]

49. Druzhinina, O.; Kublitskiy, Y.; Stančikaite, M.; Nazarova, L.; Syrykh, L.; Gedminiene, L.; Uogintas, D.; Skipityte, R.; Arslanov, K.; Vaikutiene, G. The Late Pleistocene-Early Holocene palaeoenvironmental evolution in the SE Baltic region: A new approach based on chironomid, geochemical and isotopic data from Kamyshovoye Lake, Russia. Boreas 2020, 49, 544-561. [CrossRef]

50. Nazarova, L.B.; Sapelko, T.V.; Kuznetsov, D.D.; Syrykh, L.S. Palaeoecological and Palaeoclimatical Reconstructions of Holocene According Chironomid Analysis of Lake Glubokoye Sediments. In Doklady Biological Sciences: Proceedings of the Academy of Sciences of the USSR, Biological Sciences Sections; Pleiades Publishing: New York, NY, USA, 2015; Volume 460, pp. 57-60. [CrossRef]

51. Rinterknecht, V.; Hang, T.; Gorlach, A.; Kohv, M.; Kalla, K.; Kalm, V.; Subetto, D.; Bourlès, D.; Léanni, L.; Guillou, V. The Last Glacial Maximum extent of the Scandinavian Ice Sheet in the Valday Heights, western Russia: Evidence from cosmogenic surface exposure dating using 10Be. Quat. Sci. Rev. 2018, 200, 106-113. [CrossRef]

52. Mazurkevich, A.; Dolbunova, E.; Kittel, P.; Fassbender, J.; Maigrot, Y.; Mroczkowska, A.; Płóciennik, M.; Sikora, J.; Słowiński, M.; Sablin, M. Multi-Disciplinary Research on the Neolithic Pile-Dwelling Serteya II Site (Western Russia) and the Landscape Reconstruction. Nie tylko Krzemienie. Not only flints.; Instytut Archeologii Uniwersytetu Łódzkiego, Łódzka Fundacja Badań Naukowych, Stowarzyszenie Naukowe Archeologów Polskich Oddział w Łodzi: Łódź, Poland, 2017; pp. 103-128.

53. Mazurkevich, A.; Kulkova, M.; Savel'eva, L. Geoarchaeology of the Serteya Microregion, the Upper Dvina Basin. In Geoarchaeological Issues of the Upper Dnieper-Western Dvina River Region (Western Russia); Universum: Moscow-Smolensk, Russia, 2012; pp. 49-104.

54. Mazurkevich, A.N.; Arslanov, K.A.; Savel'eva, L.A.; Kulkova, M.A.; Zaitseva, G.I. Mesolithic and Neolithic in the Western Dvina-Lovat Area. In The East European Plain on the Eve of Agriculture; BAR International Series; Archaeopress: Oxford, UK, 2009; Volume 164, pp. 145-153.

55. Kulkova, M.; Mazurkevich, A.; Dolbunova, E.; Regert, M.; Mazuy, A.; Nesterov, E.; Sinai, M. Late Neolithic Subsistence Strategy and Reservoir Effects in 14C Dating of Artifacts at the Pile-Dwelling Site Serteya II (NW Russia). Radiocarbon 2015, 57, 611-623. [CrossRef]

56. Mazurkevich, A.N.; Korotkevich, B.N.; Dolukhanov, P.M.; Shukurov, A.M.; Arslanov, K.A.; Savel'eva, L.A.; Dzinoridze, E.N.; Kulkova, M.A.; Zaitseva, G.I. Climate, subsistence and human movements in the Western Dvina-Lovat River Basins. Quaternary International. Quat. Int. 2009, 203, 52-66. [CrossRef] 
57. Kittel, P.; Mazurkevich, A.; Wieckowska-Lüth, M.; Pawłowski, D.; Dolbunova, E.; Płóciennik, M.; Gauthier, E.; Krapiec, M.; Maigrot, Y.; Danger, M. On the border between land and water: The environmental conditions of the Neolithic occupation from 4.3 until 1.6 ka BC at Serteya, Western Russia. Geoarchaeology 2021, 36, 173-202. [CrossRef]

58. Kulkova, M.; Mazurkevich, A.; Dolukhanov, P. Chronology and paleoclimate of prehistoric sites in Western Dvina-Lovat area of North-western Russia. Geochronometria: J. Methods Appl. Absol. Chronol. 2001, 20, 87-94.

59. Mazurkevich, A.; Dolbunova, E.; Kul'kova, M.; Alexandrovskiy, A.; Saveleva, L.; Polkovnikova, M.; Khrustaleva, I.; Kolosova, M.; Hookk, D.; Mazurkevich, K. Dynamics of landscape developing in early-middle Neolithics in Dnepr-Dvina region. In Proceedings of the International Conference "Geomorphic Processes and Geoarchaeology: From Landscape Archaeology to Archaeotourism"; Universum: Moscow-Smolensk, Russia, 2012; pp. 20-24.

60. Mazurkevich, A.N.; Hookk, D.Y.; Fassbinder, J. Magnetometry and susceptibility prospecting on Neolithic-early Iron Age sites at Serteya, North-West Russia. ArcheoSciences Revue D'archeometrie 2009, 33, 81-85. [CrossRef]

61. Mazurkevich, A.N. Pervyye svidetelstva proyavleniya proizvodyashchego khozyaystva na Severo-Zapade Rossii. In Pushkarevskiy sbornik II; Izd-vo S-Peterburgskogo un-ta: Sankt Petersburg, Russia, 2003; pp. 77-84.

62. Tarasov, P.E.; Savelieva, L.A.; Long, T.; Leipe, C. Postglacial vegetation and climate history and traces of early human impact and agriculture in the present-day cool mixed forest zone of European Russia. Quat. Int. 2019, 516, 21-41. [CrossRef]

63. Bond, G.; Kromer, B.; Beer, J.; Muscheler, R.; Evans, M.N.; Showers, W.; Hoffmann, S.; Lotti-Bond, R.; Hajdas, I.; Bonani, G. Persistent solar influence on North Atlantic climate during the Holocene. Science 2001, 294, 2130-2136. [CrossRef]

64. Obrochta, S.P.; Miyahara, H.; Yokoyama, Y.; Crowley, T.J. A re-examination of evidence for the North Atlantic "1500-year cycle" at Site 609. Quat. Sci. Rev. 2012, 55, 23-33. [CrossRef]

65. Bütikofer, J. Millennial Scale Climate Variability during the Last 6000 Years-Tracking down the Bond Cycles. Verlag nicht ermittelbar. 2007.

66. Solanki, S.; Usoskin, I.; Kromer, B.; Schüssler, M.; Beer, J. How unusual is today's solar activity?(reply). Nature 2005, 436, E4-E5. [CrossRef]

67. Wang, W.; Feng, Z.; Ran, M.; Zhang, C. Holocene climate and vegetation changes inferred from pollen records of Lake Aibi, northern Xinjiang, China: A potential contribution to understanding of Holocene climate pattern in East-central Asia. Quat. Int. 2013, 311, 54-62. [CrossRef]

68. Mayewski, P.A.; Rohling, E.E.; Stager, J.C.; Karlén, W.; Maasch, K.A.; Meeker, L.D.; Meyerson, E.A.; Gasse, F.; van Kreveld, S.; Holmgren, K. Holocene climate variability. Quat. Res. 2004, 62, 243-255. [CrossRef]

69. Newman, M.; Alexander, M.A.; Ault, T.R.; Cobb, K.M.; Deser, C.; Di Lorenzo, E.; Mantua, N.J.; Miller, A.J.; Minobe, S.; Nakamura, H. The Pacific decadal oscillation, revisited. J. Clim. 2016, 29, 4399-4427. [CrossRef]

70. Trigo, R.M.; Osborn, T.J.; Corte-Real, J.M. The North Atlantic Oscillation influence on Europe: Climate impacts and associated physical mechanisms. Clim. Res. 2002, 20, 9-17. [CrossRef]

71. Visbeck, M.H.; Hurrell, J.W.; Polvani, L.; Cullen, H.M. The North Atlantic Oscillation: Past, present, and future. Proc. Natl. Acad. Sci. USA 2001, 98, 12876-12877. [CrossRef]

72. Cronin, T.; Hayo, K.; Thunell, R.; Dwyer, G.; Saenger, C.; Willard, D. The medieval climate anomaly and little ice age in Chesapeake Bay and the North Atlantic Ocean. Palaeogeogr. Palaeoclimatol. Palaeoecol. 2010, 297, 299-310. [CrossRef]

73. Wanner, H.; Beer, J.; Bütikofer, J.; Crowley, T.J.; Cubasch, U.; Flückiger, J.; Goosse, H.; Grosjean, M.; Joos, F.; Kaplan, J.O.; et al. Mid- to Late Holocene climate change: An overview. Quat. Sci. Rev. 2008, 27, 1791-1828. [CrossRef]

74. Seidov, D.; Maslin, M. North Atlantic deep water circulation collapse during Heinrich events. Geology 1999, 27, 23-26. [CrossRef]

75. Jennings, A.E.; Grönvold, K.; Hilberman, R.; Smith, M.; Hald, M. High-resolution study of Icelandic tephras in the Kangerlussuaq Trough, southeast Greenland, during the last deglaciation. J. Quat. Sci. Publ. Quat. Res. Assoc. 2002, 17, 747-757. [CrossRef]

76. Peyron, O.; Combourieu-Nebout, N.; Brayshaw, D.; Goring, S.; Andrieu-Ponel, V.; Desprat, S.; Fletcher, W.; Gambin, B.; Ioakim, C.; Joannin, S. Precipitation changes in the Mediterranean basin during the Holocene from terrestrial and marine pollen records: A model-data comparison. Clim. Past 2017, 13, 249-265. [CrossRef]

77. Kulkova, M.; Chadov, F.; Davidochkina, A. Radiocarbon in vegetation of coastal zone of Finnish Bay (Russia). Procedia Environ. Sci. 2011, 8, 375-381. [CrossRef]

78. Abramov, L. Opisaniya Prirody Nashey Strany: Razvitiye Fiziko-Geograficheskikh Kharakteristik; Akademiya nauk SSSR, Institut Geografii: Moskva, Russia, 1972.

79. Kondracki, J. Fizycznogeograficzna regionalizacja republik Litewskiej i Białoruskiej w układzie dziesiętnym. Przeglad Geograficzny 1992, 64, 341-346.

80. Kobyshevoy, N.V. The Climate of Russia [Klimat Rossii], Habil. (geography). Gidrometeoizdat 2001, 655.

81. El tiempo. Available online: http:/ / www.tutiempo.net (accessed on 9 December 2019).

82. Arslanov, K.A.; Savel'eva, L.; Dzinoridze, E.; Mazurkevich, A.; Dolukhanov, P. The Holocene Environments in North-Western and Central Russia; The East European Plain on the Eve of Agriculture. BAR International Series 1964; Dolukhanov, P.M., Sarson, G.R., Shukorov, A.M., Eds.; Archaeopress: Oxford, UK, 2009; pp. 109-121.

83. Velichko, A.A.; Faustova, M.A.; Pisareva, V.V.; Gribchenko, Y.N.; Sudakova, N.G.; Lavrentiev, N.V. Chapter 26-Glaciations of the East European Plain: Distribution and Chronology. In Developments in Quaternary Sciences; Ehlers, J., Gibbard, P.L., Hughes, P.D., Eds.; Elsevier: Amsterdam, The Netherlands, 2011; Volume 15, pp. 337-359. 
84. Piech, W.; Kittel, P.; Mazurkevich, A.; Pavlovskaia, E.; Kazakov, E.; Teltevskaya, Y.; Błaszczyk, K.; Kotrys, B. Cechy sedymentologiczne i warunki depozycji osadów stożka akumulacyjnego w dolinie rzeki Sertejki (zachodnia Rosja). Acta Geogr. Lodz. 2018, 107, 215-238.

85. Kittel, P.; Mazurkevich, A.; Dolbunova, E.V.; Kazakov, E.; Mroczkowska, A.; Pavlovskaia, E.; Piech, W.; Płóciennik, M.; Sikora, J.; Teltevskaya, Y.; et al. Palaeoenvironmental reconstructions for the Neolithic pile-dwelling Serteya II site case study, Western Russia. Acta Geogr. Lodz. 2018, 107, 191-213.

86. Błaszkiewicz, M. Wytapianie się pogrzebanych brył martwego lodu w późnym glacjale i wczesnym holocenie a zdarzenia ekstremalne. Landf. Anal. 2008, 8, 9-12.

87. Błaszkiewicz, M. Późnoglacjalna i Wczesnoholoceńska Ewolucja Obniżeń Jeziornych na Pojezierzu Kociewskim (wschodnia część Pomorza); IGiPZ PAN: Warszawa, Poland, 2005; Volume 201.

88. Łuców, D.; Lamentowicz, M.; Obremska, M.; Arkhipova, M.; Kittel, P.; Łokas, E.; Mazurkevich, A.; Mróz, T.; Tjallingii, R.; Słowiński, M. Disturbance and resilience of a Sphagnum peatland in western Russia (Western Dvina Lakeland) during the last 300 years: A multiproxy, high-resolution study. Holocene 2020, 30, 1552-1566. [CrossRef]

89. Mazurkevich, A.; Kittel, P.; Maigrot, Y.; Dolbunova, E.; Mroczkowska, A.; Wieckowska-Lüth, M.; Piech, W. Natural and anthropogenic impact on the formation of archaeological layers in a lake shore area: Case study from the Serteya II site, Western Russia. Acta Geogr. Lodz. 2020, 110, 81-102.

90. Mazurkevich, A.; Sablin, M.V.; Dolbunova, E.V.; Kittel, P.; Maigrot, Y.; Kazakov, E. Landscape, Seasonality and Natural Resources Use in the 3rd Millennium BC by Pile-Dwelling Communities (NW Russia). In Settling Waterscapes in Europe: The Archaeology of Neolithic and Bronze Age Pile-Dwellings; Hafner, A.E.D., Mazurkevich, A., Pranckenaite, E., Hinz, M., Eds.; OSPA—Open Series in Prehistoric Archaeology, Band 1; Propylaeum: Heidelberg, Germany, 2020; pp. 17-35.

91. Ramsey, C.B. Bayesian analysis of radiocarbon dates. Radiocarbon 2009, 51, 337-360. [CrossRef]

92. Ramsey, C.B. Deposition models for chronological records. Quat. Sci. Rev. 2008, 27, 42-60. [CrossRef]

93. Andersen, T.; Cranston, P.; Epler, J. Chironomidae of the Holarctic Region: Keys and Diagnoses: Larvae; Scandinavian Society of Entomology, Entomological Society of Lund: Lund, Sweden, 2013.

94. Birks, H. Late-Quaternary biotic changes in terrestrial and lacustrine environments, with particular reference to north-west Europe. Handb. Holocene Palaeoecol. Palaeohydrology 1986, 3, 65.

95. Birks, H.J.B.; Gordon, A.D. Numerical Methods in Quaternary Pollen Analysis; Academic Press: Orlando, FL, USA, 1985.

96. Bennett, K.D. Determination of the number of zones in a biostratigraphical sequence. New Phytol. 1996, 132, 155-170. [CrossRef]

97. MacArthur, R.H. On the relative abundance of bird species. Proc. Natl. Acad. Sci. USA 1957, 43, 293. [CrossRef]

98. Lotter, A.; Juggins, S. POLPROF, TRAN and ZONE: Programs for Plotting, Editing and Zoning Pollen and Diatom Data. INQUA-Subcommission for the Study of the Holocene Working Group on Data-Handling Methods, Newsletter. 1991; Volume 6, pp. $4-6$.

99. Line, J.; Birks, H. BSTICK Version 1.0; Unpublished Computer Program; Botanical Institute, University of Bergen: Bergen, Norway, 1996.

100. Juggins, S. C2 Version 1.5.0: A Program for Plotting and Visualising Stratigraphic Data; University of Newcastle: Newcastle upon Tyne, UK, 2007.

101. Frey, D. Cladocera Analysis. In Handbook of Holocene Palaeoecology and Palaeohydrology; Berglund, B.E., Ed.; Wiley: Chichester, UK, 1986.

102. Szeroczyńska, K.; Sarmaja-Korjonen, K. Atlas of Subfossil Cladocera from Central and Northern Europe; Friends of Lower Vistula Society: Swiecie, Poland, 2007; pp. 1-87.

103. Van Damme, K.; Kotov, A.A.; Dumont, H.J. A checklist of names in Alona Baird 1843 (Crustacea: Cladocera: Chydoridae) and their current status: An analysis of the taxonomy of a lump genus. Zootaxa 2010, 2330, 1-63. [CrossRef]

104. Bjerring, R.; Becares, E.; Declerck, S.; Gross, E.M.; Hansson, L.-A.; Kairesalo, T.; Nykanen, M.; Halkiewicz, A.; Kornijów, R.; Conde-Porcuna, J.M.; et al. Subfossil Cladocera in relation to contemporary environmental variables in 54 Pan-European lakes. Freshw. Biol. 2009, 54, 2401-2417. [CrossRef]

105. Walanus, A.; Nalepka, D. Program for counting pollen grains, diagrams plotting and numerical analysis. Trees $1999,9,3$.

106. Faegri, K.; Iversen, J. Finding the grain: Laboratory Techniques. Textbook of Pollen Analysis. 1989; pp. 69-89.

107. Svobodová, H. M. Reille: Pollen et spores d'europe et d'afrique du nord. Folia Geobot. 1997, 32, 24. [CrossRef]

108. Van Geel, B. Non-pollen palynomorphs. In Tracking environmental change using lake sediments; Springer: Berlin/Heidelberg, Germany, 2002; pp. 99-119.

109. Van Geel, B.; Aptroot, A. Fossil ascomycetes in Quaternary deposits. Nova Hedwig. 2006, 82, 313-330. [CrossRef]

110. Beug, H. 2004: Leitfaden der Pollenbestimmung fUr Mitteleuropa und angrenzende Gebiete; Verlag Dr. Friedrich Pfeil.: München, Germany, 2004.

111. Grimm, E. Tilia Software v. 1.7.16; Illinois State Museum: Springfield, IL, USA, 2011.

112. Grimm, E. Tilia software 2.0.2.; Illinois State Museum Research and Collection Center: Springfield, IL, USA, 2004.

113. Blackford, J.; Innes, J. Linking current environments and processes to fungal spore assemblages: Surface NPM data from woodland environments. Rev. Palaeobot. Palynol. 2006, 141, 179-187. [CrossRef]

114. Luoto, T.P.; Nevalainen, L. Quantifying climate changes of the Common Era for Finland. Clim. Dyn. 2017, 49, $2557-2567$. [CrossRef] 
115. Luoto, T.P.; Nevalainen, L.; Kultti, S.; Sarmaja-Korjonen, K. An evaluation of the influence of water depth and river inflow on quantitative Cladocera-based temperature and lake level inferences in a shallow boreal lake. Hydrobiologia 2011, 676, 143-154. [CrossRef]

116. Guiot, J. Methodology of the last climatic cycle reconstruction in France from pollen data. Palaeogeogr. Palaeoclimatol. Palaeoecol. 1990, 80, 49-69. [CrossRef]

117. Marsicek, J.; Shuman, B.N.; Bartlein, P.J.; Shafer, S.L.; Brewer, S. Reconciling divergent trends and millennial variations in Holocene temperatures. Nature 2018, 554, 92-96. [CrossRef] [PubMed]

118. Mauri, A.; Davis, B.; Collins, P.; Kaplan, J. The climate of Europe during the Holocene: A gridded pollen-based reconstruction and its multi-proxy evaluation. Quat. Sci. Rev. 2015, 112, 109-127. [CrossRef]

119. Martin, C.; Menot, G.; Thouveny, N.; Peyron, O.; Andrieu-Ponel, V.; Montade, V.; Davtian, N.; Reille, M.; Bard, E. Early Holocene Thermal Maximum recorded by branched tetraethers and pollen in Western Europe (Massif Central, France). Quat. Sci. Rev. 2020, 228, 106109. [CrossRef]

120. Peyron, O.; Magny, M.; Goring, S.; Joannin, S.; de Beaulieu, J.-L.; Bruggiapaglia, E.; Sadori, L.; Garfi, G.; Kouli, K.; Ioakim, C. Contrasting patterns of climatic changes during the Holocene across the Italian Peninsula reconstructed from pollen data. Clim. Past 2013, 9, 1233-1252. [CrossRef]

121. Juggins, S. Rioja: Analysis of Quaternary Science Data: R package versión (0.9-21). 2017.

122. Ter Braak, C.J.; Šmilauer, P. CANOCO Reference Manual and CanoDraw for Windows User's Guide; Software for Canonical Community Ordination (Version 4.5); Microcomputer Power: Ithaca, NY, USA, 2002; p. 500.

123. Malmgren, B.A.; Nordlund, U. Application of artificial neural networks to paleoceanographic data. laeogeogr. Palaeoclimatol. Palaeoecol. 1997, 136, 359-373. [CrossRef]

124. Grimm, E.C. CONISS: A FORTRAN 77 program for stratigraphically constrained cluster analysis by the method of incremental sum of squares. Comput. Geosci. 1987, 13, 13-35. [CrossRef]

125. Alpat'yev, A.M.; Arkhangel'skiy, A.M.; Podoplelov, N.Y.; Stepanov, A.Y. Fizicheskaya Geografiya SSSR (Aziatskaya Chast'); Vysshaya shkola: Moskva, Russia, 1976; Volume 2, p. 360.

126. Kaufman, D.; McKay, N.; Routson, C.; Erb, M.; Dätwyler, C.; Sommer, P.S.; Heiri, O.; Davis, B. Holocene global mean surface temperature, a multi-method reconstruction approach. Sci. Data 2020, 7, 201. [CrossRef] [PubMed]

127. Levitan, M.; Lavrushin, Y.A. The Late Glacial Time and Holocene of Northern Eurasia. In Sedimentation History in the Arctic Ocean and Subarctic Seas for the Last 130 kyr; Springer: Berlin/Heidelberg, Germany, 2009; pp. 43-45.

128. Renssen, H.; Seppä, H.; Heiri, O.; Roche, D.; Goosse, H.; Fichefet, T. The spatial and temporal complexity of the Holocene thermal maximum. Nat. Geosci. 2009, 2, 411-414. [CrossRef]

129. Juggins, S. Quantitative reconstructions in palaeolimnology: New paradigm or sick science? Quat. Sci. Rev. 2013, 64, 20-32. [CrossRef]

130. Yao, Y.; Luo, D. Do European blocking events precede North Atlantic Oscillation events? Adv. Atmos. Sci. 2015, 32, 1106-1118 [CrossRef]

131. Rousi, E.; Rust, H.W.; Ulbrich, U.; Anagnostopoulou, C. Implications of winter NAO flavors on present and future European climate. Climate 2020, 8, 13. [CrossRef]

132. Beck, C.; Philipp, A.; Streicher, F. The effect of domain size on the relationship between circulation type classifications and surface climate. Int. J. Climatol. 2016, 36, 2692-2709. [CrossRef]

133. Trouet, V.; Esper, J.; Graham, N.E.; Baker, A.; Scourse, J.D.; Frank, D.C. Persistent Positive North Atlantic Oscillation Mode Dominated the Medieval Climate Anomaly. Science 2009, 324, 78-80. [CrossRef] [PubMed]

134. Mann, M.E.; Zhang, Z.; Rutherford, S.; Bradley, R.S.; Hughes, M.K.; Shindell, D.; Ammann, C.; Faluvegi, G.; Ni, F. Global Signatures and Dynamical Origins of the Little Ice Age and Medieval Climate Anomaly. Science 2009, 326, 1256-1260. [CrossRef] [PubMed]

135. Ortega, P.; Lehner, F.; Swingedouw, D.; Masson-Delmotte, V.; Raible, C.C.; Casado, M.; Yiou, P. A model-tested North Atlantic Oscillation reconstruction for the past millennium. Nature 2015, 523, 71-74. [CrossRef]

136. Moreno-Chamarro, E.; Zanchettin, D.; Lohmann, K.; Luterbacher, J.; Jungclaus, J.H. Winter amplification of the European Little Ice Age cooling by the subpolar gyre. Sci. Rep. 2017, 7, 9981. [CrossRef]

137. Pleskot, K.; Apolinarska, K.; Kołaczek, P.; Suchora, M.; Fojutowski, M.; Joniak, T.; Kotrys, B.; Kramkowski, M.; Słowiński, M.; Woźniak, M. Searching for the 4.2 ka climate event at Lake Spore, Poland. Catena 2020, 191, 104565. [CrossRef]

138. Novenko, E.Y.; Eremeeva, A.P.; Chepurnaya, A.A. Reconstruction of Holocene vegetation, tree cover dynamics and human disturbances in central European Russia, using pollen and satellite data sets. Veg. Hist. Archaeobotany 2014, 23, 109-119. [CrossRef]

139. Novenko, E.Y.; Tsyganov, A.N.; Pisarchuk, N.M.; Volkova, E.M.; Babeshko, K.V.; Kozlov, D.N.; Shilov, P.M.; Payne, R.J.; Mazei, Y.A.; Olchev, A.V. Forest history, peatland development and mid-to late Holocene environmental change in the southern taiga forest of central European Russia. Quat. Res. 2018, 89, 223-236. [CrossRef]

140. Lotter, A.F.; Birks, H.J.B.; Hofmann, W.; Marchetto, A. Modern diatom, cladocera, chironomid, and chrysophyte cyst assemblages as quantitative indicators for the reconstruction of past environmental conditions in the Alps. II. Nutrients. J. Paleolimnol. 1998, 19, 443-463. [CrossRef]

141. Brodersen, K.P.; Quinlan, R. Midges as palaeoindicators of lake productivity, eutrophication and hypolimnetic oxygen. Quat. Sci. Rev. 2006, 25, 1995-2012. [CrossRef] 
142. Chevalier, M.; Davis, B.A.; Heiri, O.; Seppä, H.; Chase, B.M.; Gajewski, K.; Lacourse, T.; Telford, R.J.; Finsinger, W.; Guiot, J. Pollen-based climate reconstruction techniques for late Quaternary studies. Earth Sci. Rev. 2020, 210, 103384. [CrossRef]

143. Telford, R.J. Review and test of reproducibility of subdecadal resolution palaeoenvironmental reconstructions from microfossil assemblages. Quat. Sci. Rev. 2019, 222, 105893. [CrossRef]

144. Brooks, S.J. Fossil midges (Diptera: Chironomidae) as palaeoclimatic indicators for the Eurasian region. Quat. Sci. Rev. 2006, 25, 1894-1910. [CrossRef]

145. Flössner, D. Krebstiere, Crustacea. Kiemen-und Blattfüßer, Branchiopoda Fischläuse, Branchiura. Die Tierwelt Deutschlands 60. Teil. Jena 1972.

146. Luoto, T.P.; Kultti, S.; Nevalainen, L.; Sarmaja-Korjonen, K. Temperature and effective moisture variability in southern Finland during the Holocene quantified with midge-based calibration models. J. Quat. Sci. 2010, 25, 1317-1326. [CrossRef]

147. Nosova, M.B.; Novenko, E.Y.; Severova, E.E.; Volkova, O.A. Vegetation and climate changes within and around the PolistovoLovatskaya mire system (Pskov Oblast, north-western Russia) during the past 10,500 years. Veg. Hist. Archaeobotany 2019, 28, 123-140. [CrossRef]

148. Koff, T. Pollen Profile LIIVJARV; Liivjarve Bog: Estonia, 2010. [CrossRef]

149. Pirrus, R.; Rouk, A.; Liiva, A. Geology and stratigraphy of the reference site of Lake Raigastvere in Saadjärv drumlin field. Palaeohydrology Temp. Zone II. Lakes 1987, 101-122.

150. Novenko, E.Y.; Tsyganov, A.N.; Volkova, E.M.; Babeshko, K.V.; Lavrentiev, N.V.; Payne, R.J.; Mazei, Y.A. The Holocene paleoenvironmental history of central European Russia reconstructed from pollen, plant macrofossil, and testate amoeba analyses of the Klukva Peatland, Tula Region. Quat. Res. 2015, 83, 459-468. [CrossRef]

151. Elovicheva, Y. Novye razrezy golotsena Belarusii (New Holocene sections in Byelorussia). Geologicheskoe stroenie osadochnoi tolshchi Belorussii (Geological composition of sedimentary sequence of Byelorussia). 1985; pp. 141-169.

152. Shulija, K.; Lujanas, V.; Kibilda, Z.; Banys, J.; Genutiene, I. Stratigraphy and chronology of lacustrine and bog deposits of the Bebrukas Lake hollow. Tr. Instituta Geol. Vilnius 5. 1967.

153. Ralska-Jasiewiczowa, M.; Latalowa, M. Poland. Palaeoecological events during the last 15,000 years: Regional syntheses of palaeoecological studies of lakes and mires in Europe. 1996.

154. Yelovicheva, Y. Pleistocene nature events of the Central and Middle-East Europe for the comprehension of their development in the future (by palynological data). Quaternary stratigraphy and paleontology of the southern russia: Connections between Europe, Africa and Asia. 2010; p. 198.

155. Binka, K.; Madeyska, T.; Marciniak, B.; Seroczynska, K.; Wieckowski, K. Bledowo Lake (central Poland): History of vegetation and lake development during the last 12 kyr. Bull Acad. Pol. Sci 1988, 36, 147-158.

156. Noryśkiewicz, B. Zmiany szaty roślinnej okolic Jeziora Biskupińskiego pod wpływem czynników naturalnych i antropogenicznych w późnym glacjale i holocenie. In Zarys zmian środowiska geograficznego okolic Biskupina pod wpływem czynników naturalnych i antropogenicznych w późnym glacjale i holocenie; Turpress: Torun, Poland, 1995; pp. 147-179.

157. Bezusko, L. History of vegetation of the north western part of Small Polesye in Holocene. Ukr. Bot. J. 1977, 3, $294-298$.

158. Peichlová, M. Historie vegetace Broumovska. [Vegetation history of the Broumovsko Region]; Ms. Cand. diss.; Academy of Science CR: Pruhonice, Czech Republic, 1979.

159. Sillasoo, U.; Mauquoy, D.; Blundell, A.; Charman, D.; Blaauw, M.; Daniell, J.R.; Toms, P.; Newberry, J.; Chambers, F.M.; Karofeld, E. Peat multi-proxy data from Männikjärve bog as indicators of late Holocene climate changes in Estonia. Boreas 2007, 36, 20-37. [CrossRef]

160. Lamentowicz, M.; Kołaczek, P.; Mauquoy, D.; Kittel, P.; Łokas, E.; Słowiński, M.; Jassey, V.E.J.; Niedziółka, K.; Kajukało-Drygalska, K.; Marcisz, K. Always on the tipping point-A search for signals of past societies and related peatland ecosystem critical transitions during the last 6500 years in N Poland. Quat. Sci. Rev. 2019, 225, 105954. [CrossRef] 